\title{
Posjedi samostana Sv. Marije u Zadru u 16. stoljeću (1562. - 1564.)
}

U radu se na temelju službenoga izvješća zastupnika (prokuratora) ženskoga benediktinskog samostana Sv. Marije u Zadru razmatra stanje samostanskih posjeda u drugoj polovini 16. stoljeća (1562. - 1564.). Izvješće je danas pohranjeno u fondu mletačke magistrature Sopraintendenti alle decime del clero u Državnom arhivu u Veneciji (Archivio di Stato di Venezia). S obzirom na vrijednost zapisanih podataka i činjenicu da u Arhivu samostana Sv. Marije u Zadru, koliko je poznato, nema sustavnih podataka o njegovim posjedima za razmatrano razdoblje, izvješće o posjedima benediktinki Sv. Marije izvrstan je prilog poznavanju gospodarskoga stanja i ekonomskih interakcija zadarskih redovnica u 16. stoljeću kao dodatak dosadašnjim rezultatima znanstvenih istraživanja. Usto su navedeni podatci, a napose popis kolona u pojedinim selima koja su bila u posjedu samostana, prvorazredno vrelo za istraživanje povijesne antroponimije i toponimije Zadra i njegova širega okružja.

Ključne riječi: samostan Sv. Marije, benediktinke, Zadar, posjedi, 16. stoljeće

\section{Uvod}

Ženski benediktinski samostan Sv. Marije u Zadru proslavio je 2016. godine 950. obljetnicu postojanja i djelovanja. Tom prigodom održan je znanstveni kolokvij, a nedavno je u izdanju Sveučilišta u Zadru i samostana benediktinki Sv. Marije u Zadru ugledao svjetlo dana zbornik radova s toga znanstvenoga kolokvija. ${ }^{1}$

Zdenko Dundović, Teološko-katehetski odjel, Sveučilište u Zadru, Mihovila Pavlinovića 1, 23000 Zadar, Republika Hrvatska, E-mail adresa: zdundovic@unizd.hr

1 Pavuša Vežić, Ivan Josipović, ur., Abbatissa ingenuitate precipua. Zbornik radova sa znanstvenog kolokvija „950. obljetnica Samostana benediktinki Sv. Marije u Zadru (1066. - 2016.)” (Zadar: Sveučilište u Zadru; Samostan benediktinki Sv. Marije u Zadru, 2020). 
Jednako je o 900. obljetnici Vekenegina epitafa objavljen zbornik radova. ${ }^{2}$ Dakle, znanstvenoga interesa za istraživanje prošlosti samostana Sv. Marije ne manjka, što opravdava njegov status važnoga crkvenoga, kulturno-umjetničkoga i povijesnog mjesta ne samo na lokalnoj nego i nacionalnoj razini. Doda li se tome činjenica da su zadarske benediktinke desetljećima čuvarice umjetničke baštine Zadarske nadbiskupije, a u sklopu samostana djeluje Stalna izložba crkvene umjetnosti u Zadru, ne čudi što znanstvenici dugi niz godina s interdisciplinarnoga motrišta promatraju prošlost toga samostana. ${ }^{3}$ Povijesne crtice o samostanu zapisane su u radovima zadarskoga arhiđakona i povjesničara Carla Federica Bianchija ${ }^{4}$ te u neizostavnoj trilogiji o prošlosti benediktinskoga reda u Hrvatskoj autora Ivana Ostojića. ${ }^{5}$

U ovom radu stavlja se naglasak na gospodarsko stanje samostana Sv. Marije u Zadru u drugoj polovini 16. stoljeća (1562. - 1564.), a glavni predmet istraživanja čini izvješće o samostanskim posjedima pod naslovom Description delli beni stabilj, intrade et uside delli tre anni 1562. 1563. 1564. del Monasterio delle Reuerende Monache de Santa Maria, da Zara, koje je pohranjeno u Državnom arhivu u Veneciji (Archivio di Stato di Venezia). ${ }^{6}$ Izvješće su 25. listopada 1564. sastavili samostanski prokuratori ${ }^{7}$, zadarski plemići Bernardin Galelli i Donat Krišava, te ga predali apostolskom podsakupljaču (subcollectore) crkvene desetine, zadarskom arhiđakonu te kanoniku Santu de Santiju radi određivanja iznosa crkvene desetine koju je samostan Sv. Marije trebao platiti Svetoj stolici. ${ }^{8}$ Na poleđini izvješća

\footnotetext{
2 Pavuša Vežić, Ivan Josipović, ur., Laude nitens multa. Zbornik radova s kolokvija u povodu 900. obljetnice Vekenegina epitafa (Zadar: Sveučilište u Zadru, 2018).

3 Vidi primjerice: Viktor Novak, ur., Zadarski kartular samostana Svete Marije (Zagreb: Jugoslavenska akademija znanosti i umjetnosti, 1959); Grga Novak, Vjekoslav Maštrović, ur., Kulturna baština samostana Sv. Marije u Zadru (Zadar: Institut Jugoslavenske akademije znanosti i umjetnosti u Zadru, 1968); Marijan Grgić, Časoslov opatice Čike (Zagreb: Kršćanska sadašnjost, 2002).

4 Vidi: Carlo Federico Bianchi, Zara Cristiana, sv. I (Zadar: Tipografia Woditzka, 1877), 314-334; Carlo Federico Bianchi, Fasti di Zara (Zadar: Tipografia Woditzka, 1888).

5 Ivan Ostojić, Benediktinci u Hrvatskoj i ostalim našim krajevima, sv. II (Split: Benediktinski priorat - Tkon, 1964), 73-85.

${ }_{6}$ Italija (dalje: IT) - Archivio di Stato di Venezia (dalje: ASVe) - fond 0450 - Sopraintendenti alle decime del clero (dalje: SDC), pezzo 39, br. 5.

7 Svaki samostan imao je svojega zastupnika, i to plemića samostani u kojima su redovnice bile plemkinje (što je ovdje bio slučaj), i građanina samostani u kojima su redovnice bile građanskoga podrijetla. Prokuratori su se birali doživotno i sebi prisvajali veća prava od onih koja su im pripadala. Koludrice su same birale zastupnike, bez odobrenja zadarskoga nadbiskupa, zbog čega je zadarski nadbiskup Minuccio Minucci na partikularnoj sinodi donio odredbu protiv takva običaja te predložio da se zastupnici (prokuratori) samostana biraju na tri godine. Josip Kolanović, „Zadarska nadbiskupija prema izvješćima ad limina 1599. - 1797.", u: Sedamnaest stoljeća zadarske Crkve. Zbornik radova znanstvenog skupa o 1700. obljetnici mučeništva sv. Stošije (Anastazije) 16. - 18. studenoga 2004., ur. Livio Marijan (Zadar: Zadarska nadbiskupija, 2010), 395.

8 O oporezivanju i sakupljanju poreza, odnosno izvorima prihoda Apostolske stolice vidi opširno u: Jadranka Neralić, Put do crkvene nadarbine (Split: Književni krug, 2007), 57-99.
} 
zapisano je da je bila riječ o iznosu od 383 lire, iz čega se može zaključiti da su godišnji prihodi samostana iznosili oko 618 dukata, što se poklapa s dosadašnjim spoznajama u literaturi. ${ }^{10}$ Opatica samostana Sv. Marije bila je tada Frančeska Krnarutić. ${ }^{11}$

Prvi apostolski sakupljači desetine zabilježeni su početkom 13. stoljeća. Redovito su bili stručnjaci za građansko i kanonsko pravo, u rangu kapelana, kanonika ili arhiđakona. Ubiranje desetine postalo je toliko opsežno da se pokazalo nužnim imenovanje podsakupljača u svakoj biskupiji. Potkraj 13. stoljeća podsakupljači desetine bili su uglavnom čelnici redovničkih ustanova, a ta se praksa nastavila i početkom 14. stoljeća. Uobičajeni postupak ubiranja desetine tekao je otprilike ovako: porezni obveznik ili njegov zastupnik (procurator) osobno bi se pojavili pred sakupljačem (ili u ovom slučaju podsakupljačem) da utvrde iznos koji treba uplatiti, rokove uplate, kazne koje će biskup poduzeti ako se obveza ne ispuni; za oduzimanjem (sequestrum) posezalo se i prije nego što bi porezni obveznik obećao uplatu pristojbe, ali i kasnije u slučaju neizvršene uplate. ${ }^{12}$

Izvješća o porezu na prihode jedne crkvene institucije svjedoče o njezinu materijalnom stanju, a opisi pojedinih posjeda omogućuju analizu njihova gospodarskoga poslovanja. U ovom slučaju primijenit će se sljedeća metodologija: najprije će se prikazati zemljišni posjedi samostana Sv. Marije razdijeljeni u tri kategorije: na kopnu, u gradu i njegovoj okolici te otočni posjedi. Potom će se prikazati prihodi gradskih nekretnina u posjedu samostana Sv. Marije, razdijeljeni u dvije kategorije: nekretnine u izravnom najmu (affitto) i zakupi (livelli). U prilogu radu donosi se izvorni prijepis o samostanskim nekretninama u gradu i Varošu zbog navedenih imena i prezimena zakupnika, kao i pojedinih lokaliteta, što je vrijedan izvor za proučavanje zadarske povijesne antroponimije i toponimije. Pri čitanju je nužno uzeti u obzir specifičnosti dalmatinskoga kolonata, koji razlikuje pojmove kmetstvo i težaština. Kmetstvo označava rad kolona na ždrijebu oranice, a težaština pretpostavlja rad kolona u vinogradu, zbog čega su u izvješću na pojedinom posjedu te dvije kategorije razdvojene iako se radnici nazivaju zajedničkim nazivom koloni (coloni) te se u tabličnim prikazima koristi taj pojam. ${ }^{13} \mathrm{~S}$ obzirom na to da su u izvješću zasebno navedeni najmitelji i težaci (lauoratori)

\footnotetext{
9 IT-ASVe-0450-SDC, pezzo 39, br. 5, neozn. fol.

10 Amos Rube Filipi, „Samostan i crkva Sv. Marije u Zadru prema dokumentima iz g. 1579. i 1603.”, u: Kulturna baština samostana Sv. Marije u Zadru, ur. Grga Novak i Vjekoslav Maštrović (Zadar: Institut Jugoslavenske akademije znanosti i umjetnosti u Zadru, 1968), 241.

11 Služba opatice tada je trajala doživotno. Filipi, „Samostan i crkva Sv. Marije”, 237.

12 Jadranka Neralić upozorila je na to da o podsakupljačima u Dalmaciji ima dosta nepoznanica. Neralić, Put do crkvene nadarbine, 82.

${ }_{13}$ O dalmatinskom kolonatu, kmetstvu i težaštini te općenito o zemljišnim odnosima vidi opširno u: Tomislav Raukar, Zadar u XV. stoljeću. Ekonomski razvoj i društveni odnosi (Zagreb: Sveučilište u Zagrebu, Institut za hrvatsku povijest, 1977), 80-104.
} 
koji su obrađivali samostanske zemlje u blizini grada, a uzevši u obzir da je težaština nastala u uvjetima gradske privrede, pa se može označiti gradskim tipom agrarnih odnosa ${ }^{14}$, u tabličnom prikazu koristi se pojam težak. Na kraju će se prikazati rashodi, odnosno troškovi samostana Sv. Marije u Zadru u razmatranom razdoblju.

\section{Zemljišni posjedi samostana Sv. Marije u Zadru (1562. - 1564.)}

O načinu stjecanja zemljišnih posjeda samostana Sv. Marije u Zadru pregršt podataka iznio je Eduard Peričić. ${ }^{15}$ Autor je ujedno upozorio na računske knjige samostana koje su do danas sačuvane i potječu iz posljednjih desetljeća 15. stoljeća, pa se svojim podatcima nastavljaju do sredine 19. stoljeća. U tim knjigama, pohranjenim u Arhivu samostana Sv. Marije u Zadru, spominju se mnogi samostanski posjedi na kopnu i otocima, kao i brojne samostanske nekretnine u samome gradu. Izvješće koje se ovdje razmatra potvrđuje Peričićeve navode da je samostanska ekonomija tijekom prve polovine 16. stoljeća bilježila redovite prihode, a da se u drugoj polovini stoljeća situacija znatno pogoršala zbog učestalih osmanskih provala i mletačko-osmanskih sukoba na tom području. ${ }^{16}$ To potvrđuju i drugi izvori, primjerice apostolskih vizitacija samostana iz 1579. i 1603 . godine. ${ }^{17}$

Budući da u spomenutim računskim knjigama nije zabilježen sustavan prikaz svih samostanskih posjeda, jer je uglavnom riječ o registrima uplata, izvješće samostanskih zastupnika daje kvalitetniji uvid u sve samostanske posjede u razdoblju 1562. - 1564., s navedenim prostornim veličinama ždrijebova zemljišta na pojedinom posjedu, imenima i prezimenima kolona, obrađivača samostanskih vinograda te nizom korisnih podataka o samostanskoj ekonomiji. Popis posjeda u drugoj polovini 16. stoljeća brojčano se nije bitno razlikovao od naznačenih samostanskih posjeda u prvoj polovini toga stoljeća. ${ }^{18}$ Očito je da strukturna podjela samostanskih zemljišnih posjeda u drugoj polovini 16. stoljeća nije odmaknula dalje od one zabilježene u 15. stoljeću u zadarskom okružju. Naime, na ratarskom području koje obilježava oranica temelj zemljišnoga posjeda činila je kmetska jedinica ili ždrijeb (lat. sors; tal. sorte). Više ždrijebova tvorilo je zemljoposjed, selo ili villu jednoga zemljovlasnika. ${ }^{19}$

\footnotetext{
14 Raukar, Zadar u XV. stoljeću, 90.

15 Eduard Peričić, „Samostan sv. Marije u Zadru od njegova osnutka do danas”, u: Kulturna baština samostana Sv. Marije u Zadru, ur. Grga Novak i Vjekoslav Maštrović (Zadar: Institut Jugoslavenske akademije znanosti i umjetnosti u Zadru, 1968), 7-59.

16 Peričić, „Samostan sv. Marije”, 44.

17 Filipi, „Samostan i crkva Sv. Marije”, 240.

18 Usp. Peričić, „Samostan sv. Marije”, 45.

19 Sastav ville vidi u: Raukar, Zadar u XV. stoljeću, 166-167.
} 


\section{Posjedi na kopnu}

U Stomorinu selu (Villa Stomorino selo) samostan Sv. Marije posjedovao je 22 ždrijeba zemljišta (de sorte $\left.n .^{\circ} X X I J\right)$, koje su obrađivali sljedeći koloni: Luka Babić (gastald u Stomorinu selu), Ivan Brzović, Mate Margitić, Mikloš Budačić, Bare Jačić, Juraj Kolžanić, Jeronim Bančić, svećenik Andrija Klišanin, Katarina Mojnikova, Ivan Raić, Toma Smoljić, Petar Kušterić, Martin Bilov, Juraj Pavićević, Mate Sabić, Šimun Strnotić, Nikola Boško, Martin Ljutica, Marko Prgomelja, Juraj Kutalj i Andrija Maroić. ${ }^{20}$ Stomorino selo nazivalo se nekad selo Sv. Marije u Obrovcu ili Stomorina vas kao dio Babinduba, a ubicirala ga je u svojem radu Ivna Anzulović. ${ }^{21}$ Autorica pritom misli da je Stomorina vas „ona površina zemlje od $40 \check{z}$ drijebova koju godine 1297. samostan sv. Marije, na području svoga samostana zvanog Obrovac, daje u zakup svojim stanovnicima". ${ }^{22}$ Ako su te pretpostavke točne, onda je zbog nepoznatoga razloga posjed Stomorina sela u 16 . stoljeću umanjen za 18 ždrijebova zemljišta.

Obveza kolona bila je podavati samostanu prinose žita sa zgona ${ }^{23}$, darove ili honorancije (honoranze) i dominikal u iznosu od četvrtine prinosa. ${ }^{24}$ Upisi o kolonima u službenom izvješću samostanskih zastupnika potvrđuju da je u drugoj polovini 16. stoljeća i dalje bila sačuvana tradicionalna struktura kolonatskih ugovora. ${ }^{25}$

Na posjedu u Stomorinu selu uzgajala se pšenica, ječam, proso, raž, krupnik (pir) veliki i mali, bob, crni slanutak (cesara) i manarola. U vrijeme sjetve na zgonu samostan se obvezao priskrbiti pšenicu za sjetvu. Prema ugovorima iz 16. stoljeća, kolon je bio dužan obrađivati zgon na kojem se mogla posijati velika kvarta žita. ${ }^{26}$ U slučaju Stomorina sela naznačeno je da se radilo o 16 i pol velikih kvarta žita, za što je samostan Sv. Marije, prema zapisu, davao 9 mletačkih stara pšenice za sjetvu. ${ }^{27} \mathrm{~S}$ obzirom na to da su na posjedu Stomorino selo bila 22 ždrijeba zemlji-

20 Stomorino selo imalo je crkvu sv. Petra i bilo je vlasništvo zadarskoga benediktinskog samostana Sv. Marije. Selo se nekada zvalo i Stomorina Vas. Granice sela navodi: Ivna Anzulović, „Razgraničenje između mletačke i turske vlasti na zadarskom prostoru 1576. godine, nakon Ciparskog rata”, Zadarska smotra 47 (1998), br. 1-3: 92-93.

${ }^{21}$ Ivna Anzulović, „Crkva sv. Marije od Duba ili Stublja, njezin položaj i srednjovjekovna sela na području nekadašnjeg Obrovca jugoistočno od Zadra”, Diadora 22 (2007): 309-313.

22 Anzulović, „Crkva sv. Marije od Duba”, 312.

${ }^{23}$ Zgon ili alodijalno zemljište je skup oranica u zemljoposjednikovu vlasništvu, a rad na zgonu oblik je tlake koji je najčešće i najteže opterećivao kmeta. Ipak, za zadarsko područje nužno je uzeti u obzir različite ugovore i prakse oko rada na zgonu. O tome više u: Raukar, Zadar u XV. stoljeću, 174-177.

${ }^{24}$ Identično kao i u 15. stoljeću. Usp. Raukar, Zadar u XV. stoljeću, 182.

25 Usp. Tomislav Raukar et al., Zadar pod mletačkom upravom (Zadar: Narodni list; Filozofski fakultet Zadar, 1987), 251-252.

${ }_{26}$ Zapremnina velike zadarske kvarte iz 16. stoljeća nije točnije poznata, ali se općenito uzima da je zahvaćala 133 litre. Raukar, Zadar u XV. stoljeću, 180, bilj. 121.

27 IT-ASVe-0450-SDC, pezzo 39, br. 5, neozn. fol. 
šta, ispada da je zgon po ždrijebu iznosio manje od jedne velike kvarte (izraženo u količini posijanoga sjemenja) ili oko 2 i pol gonjaja na ždrijeb. ${ }^{28}$ Uzme li se u obzir da je mletački star iznosio 83,318 litara ${ }^{29}$, proizlazi da se na jednom zgonu u Stomorinu selu sijalo oko 45,5 litara pšenice. ${ }^{30} \mathrm{Uz}$ to se kolonima tijekom pripremnih radnji na zemljištu za sjetvu podavalo meso, vino, sir, luk, sol, ulje i kruh. U pripremi tla na zgonu sudjelovale su i žene, koje su čistile korov (solano), a za taj posao bile su plaćene 4 solda po glavi. ${ }^{31}$ Jednako se postupalo u vrijeme žetve i svih radnji povezanih sa skladištenjem žitarica. Tablično se prikazuju prinosi izraženi u mletačkim starima i kvartama te vrste žitarica koje su se uzgajale na posjedu Stomorino selo za razdoblje 1562. - 1564. (tablica 1).

Tablica 1. Vrsta i količina prinosa žitarica sa samostanskoga posjeda Stomorino selo za razdoblje 1562. - 1564. godine

\begin{tabular}{|l|c|c|c|c|c|c|c|c|}
\hline \multirow{2}{*}{ Vrsta žitarice } & \multicolumn{2}{|c|}{1562.} & \multicolumn{2}{c|}{1563.} & \multicolumn{2}{c|}{1564.} & \multicolumn{2}{c|}{ Ukupno } \\
\cline { 2 - 10 } & Stara & Kvarti & Stara & Kvarti & Stara & Kvarti & Stara & Kvarti \\
\hline Pšenica & 118 & - & 109 & 2 & 56 & - & $\mathbf{2 8 3}$ & $\mathbf{2}$ \\
\hline Ječam & 80 & - & 102 & 2 & 27 & - & $\mathbf{2 0 9}$ & $\mathbf{2}$ \\
\hline Proso & 4 & 1 & 21 & - & 4 & - & $\mathbf{2 9}$ & $\mathbf{1}$ \\
\hline Raž & 6 & - & - & - & - & 3 & $\mathbf{6}$ & $\mathbf{3}$ \\
\hline Krupnik veliki & 5 & - & 7 & - & 6 & - & $\mathbf{1 8}$ & - \\
\hline Krupnik mali & 16 & - & 11 & & 4 & - & $\mathbf{3 1}$ & - \\
\hline Bob & 4 & - & 10 & - & - & 3 & $\mathbf{1 4}$ & $\mathbf{3}$ \\
\hline Crni slanutak & 1 & - & 4 & - & - & 1 & $\mathbf{5}$ & $\mathbf{1}$ \\
\hline Manarola & - & 2 & - & - & - & 1 & - & $\mathbf{3}$ \\
\hline
\end{tabular}

Samostan je kolonima isplaćivao naknadu za prijevoz žitarica s alodijalnoga zemljišta (zgona) do samostanske kurije u visini od 4 solda po staru. Koloni koji su obrađivali samostanske vinograde smještene uokolo Stomorina sela (in pertinen$z e$ ) bili su dužni dati samostanu dominikal u iznosu od četvrtine uroda (il quarto per il diretto dominio), a tri četvrtine zadržavali su za sebe. ${ }^{32}$ Samostan je zasebno plaćao radnike koji su se brinuli o proizvodnji vina, kao i one zadužene za prijevoz mošta do samostanske kurije odnosno gospodarskih zgrada. Slična raspodjela prava i obveza obiju strana primjenjivala se na svim vinogradima u posjedu samostana Sv. Marije u Zadru. Usto je samostan novčano pomagao obrađivačima vinograda pri novim nasadima vinograda, a taj je iznos varirao između 9 i 12

\footnotetext{
28 Usp. Raukar, Zadar u XV. stoljeću, 181.

29 Usp. Josip Kolanović, „Šibenski metrološki sustav u XV. stoljeću”, Arhivski vjesnik 37 (1994): 206.

30 Tomislav Raukar navodi da je za površinu od 1 ha bilo potrebno $180 \mathrm{~kg}$ sjemenja, odnosno 236 litara. Na jedan gonjaj zemljišta otpada 56 litara sjemenja. Raukar, Zadar u XV. stoljeću, 181, bilj. 122 .

31 IT-ASVe-0450-SDC, pezzo 39, br. 5, fol. 1v.

32 IT-ASVe-0450-SDC, pezzo 39, br. 5, fol. 2r.
} 
lira po gonjaju vinograda. ${ }^{33}$ Sveukupno je samostan od 1562. do 1564. sa svih samostanskih posjeda na kopnenom području uprihodio 1653 modija (moza) vina, što iznosi 69426 litara. $^{34}$ Tablično se prikazuju imena i prezimena kolona koji su obrađivali samostanske vinograde u Stomorinu selu, s naznačenom veličinom vinograda u gonjajima i pertikama (tablica 2). ${ }^{35}$

Tablica 2. Imena i prezimena kolona koji su obrađivali samostanske vinograde u Stomorinu selu, s naznačenom veličinom vinograda u gonjajima i pertikama

\begin{tabular}{|l|l|c|c|}
\hline \multicolumn{2}{|c|}{ Kolon } & \multirow{2}{*}{ Gonjaja } & \multirow{2}{*}{ Pertika } \\
\hline Ime i prezime & Izvornik & 1 & 8 \\
\hline Andrija Maroić & Andrea Maroijch & 1 & 88 \\
\hline Bare Jačić & Bare Jachich & 1 & 96 \\
\hline Ivan Raić & Zuane Raich & 3 & 30 \\
\hline Ivan Raić & il detto Zuane & - & 341 \\
\hline Juraj Kosović & Zorzi Chossouich & 1 & 44 \\
\hline Juraj Sabičević & Zorzi Sabichieuich & 1 & 44 \\
\hline Mate Sabić & Mattio Sabich & 1 & 247 \\
\hline Šimun Strnokosić & Simon Sternocossich & - & 275 \\
\hline Mate Margitić & Mattio Marghitich & 4 & 314 \\
\hline Luka Babić & Luca Babich & - & 379 \\
\hline Juraj Kužinić & Zorzi Chusinich & - & 319 \\
\hline Martin Miličević & Martin Millichieuich & 1 & 246 \\
\hline Svećenik Andrija Klišanin & p. Andrea Chglissanin & 4 & 282 \\
\hline Svećenik Ivan Drušković & p. Zuane Druscouich & - & 319 \\
\hline Mikloš36 & Michlos & 1 & 303 \\
\hline Petar Kuštera & Piero Custera & 1 & 185 \\
\hline Martin Bilov & Martin Bilof & 2 & 82 \\
\hline Kate Mojnica & Cate Moyniça & 1 & 164 \\
\hline Marko Prgomerić (Prgomelja) & Marco Pergomerich & 1 & 86 \\
\hline Martin Miličević & Martin Millichieuich & 1 & 262 \\
\hline Juraj Kuzmić & Zorzi Cusmich & 1 & 168 \\
\hline Nikola Boško & Nicolo Bosco & $\mathbf{3 5}$ & $\mathbf{1 0 0}$ \\
\hline Ukupno & & &
\end{tabular}

\footnotetext{
33 Tomislav Raukar naveo je da je ta novčana pripomoć varirala ovisno o radnim uvjetima na određenom zemljištu. Raukar, Zadar u XV. stoljeću, 184.

${ }^{34}$ Zadarski modij od 13. do 17. stoljeća iznosio je 42 litre, što je ekvivalent mletačkoj kvarti za tekućine. Marija Zaninović-Rumora, „Stare mjere za tekućine”, Radovi Zavoda za povijesne znanosti HAZU u Zadru 39 (1997): 189.

${ }_{35}$ Od 16. stoljeća zadarski gonjaj ili gonjal iznosio je $2363 \mathrm{~m}^{2}$. Gonjaj je sadržavao 400 pertika. Marija Zaninović-Rumora, „Stare mjere za površinu u sjevernoj Dalmaciji”, Radovi Zavoda za povijesne znanosti HAZU u Zadru 35 (1993): 127.

${ }^{36}$ Vjerojatno je riječ o prije spomenutom kolonu Miklošu Budačiću.
} 
Uz te, samostan je na području Stomorina sela posjedovao dodatnih 40 gonjaja vinograda, za koje je naznačeno da ih obrađuju koloni della detta Villa Stomorino selo. ${ }^{37}$

U Opatica selu (Villa chiamata Opatiza Selo) samostan Sv. Marije posjedovao je 18 ždrijebova (sors). S obzirom na to da je na zadarskom i ninskom teritoriju postojalo više sela toga imena, nužno je naglasiti da se ovdje radi o onome koje bilo smješteno na području današnjega Smokovića, a možda i na dijelu današnje Murvice (jugoistočni dio). ${ }^{38}$ Selo se prostiralo jugoistočno od Artikova sela. ${ }^{39}$

Samostanski posjed u Opatica selu iznajmljen je 1562. zadarskome mesaru Juliju Toniniju i Mihovilu Bajčinoviću iz Opatica sela za 83 dukata i 2 lire godišnje najamnine. ${ }^{40}$ Zbog najma posjeda 1562 . samostan je uprihodio samo novčanu rentu, a naturalna je pripadala najmiteljima. ${ }^{41}$ Jednako vrijedi za 1564., kada su za isti novčani iznos posjed unajmili mesar Julije Tonini i njegovi udruženici. ${ }^{42}$ Zbog toga su u izvješću samostanskih prokuratora navedeni prinosi žitarica $\mathrm{s}$ toga posjeda samo za 1563. godinu (tablica 3), kao i koloni koji su te godine obrađivali samostanske ždrijebove: Petar Držalić, Martin Ismegović, Martin Šimunović, Petar Inojević, Grgur Belulović, Vid Škaričić, Andrija Bilogović, Staniša Cvitić, Ivan Katić, Marko Zorić, Toma Balenović, Jakov Ovčinović, Andrija Klarić, Klara Cvitića i Andrija Stipičić.

Tablica 3. Vrsta i količina prinosa žitarica sa samostanskoga posjeda Opatica selo za 1563. godinu

\begin{tabular}{|l|c|}
\hline \multirow{2}{*}{ Vrsta žitarice } & Količina \\
\cline { 2 - 2 } & Stara \\
\hline Pšenica & 33 \\
\hline Ječam & 40 \\
\hline Proso & 7 \\
\hline Raž stera & 22 \\
\hline Krupnik veliki & 3 \\
\hline Krupnik mali & 6 \\
\hline Mahunarke & 26 \\
\hline Ukupno & $\mathbf{1 3 7}$ \\
\hline
\end{tabular}

37 IT-ASVe-0450-SDC, pezzo 39, br. 5, fol. 2v.

38 O tome opširnije u: Anzulović, „Razgraničenje između mletačke i turske vlasti”, 87-88.

39 Anzulović, „Razgraničenje između mletačke i turske vlasti”, 91.

40 IT-ASVe-0450-SDC, pezzo 39, br. 5, fol. 2v.

41 Tomislav Raukar ustvrdio je da su izravne komutacije naturalne u novčanu rentu bile izvanredno rijetke u zadarskom agraru. Raukar, Zadar u XV. stoljeću, 185.

42 IT-ASVe-0450-SDC, pezzo 39, br. 5, fol. 3v. 
Svake godine u Opatica selu samostan je davao 7 stara i 2 kvarte pšenice za sjetvu ${ }^{43}$, što pokazuje da su kmetovi na posjedima samostana Sv. Marije u 16. stoljeću, po svemu sudeći, ipak obrađivali manji zgon, u okvirima onoga iz 15. stoljeća. ${ }^{44}$

U Opatica selu vinograde su obrađivali sljedeći koloni, s uobičajenim podavanjem dominikala od četvrtine prinosa (tablica 4).

Tablica 4. Imena i prezimena kolona koji su obrađivali samostanske vinograde u Opatica selu, s naznačenom veličinom vinograda u gonjajima i pertikama

\begin{tabular}{|l|l|c|c|}
\hline \multicolumn{2}{|c|}{ Kolon } & \multirow{2}{*}{ Gonjaja } & \multirow{2}{*}{ Pertika } \\
\hline Ime i prezime & Izvornik & 1 & 223 \\
\hline Marko Zorić & Marko Corich & - & $341 / 4$ \\
\hline Petar Vrsaljić & Piero Varsalich & 2 & 195 \\
\hline Staniša Cvitić & Stanissa Cuitich & 3 & 32 \\
\hline Vid Škaričić & Vido Scaricich & 2 & 192 \\
\hline Grgur Belulović & Gregor Bellulouich & 3 & 322 \\
\hline Jakov Ovčinović & Giac(om)o Ofcinouich & 2 & 112 \\
\hline Petar Držalićc & Piero Darsalich & 1 & 303 \\
\hline Andrija Klarić & And(re)a Clarich & 2 & 200 \\
\hline Petar Inojević & Piero Inoeuich & 3 & 120 \\
\hline Mihovil Bajčinović & Mich(e)l Baycinouich & 2 & 86 \\
\hline Ivan Katić & Zuane Catich & 3 & 117 \\
\hline Mihovil Bajčinović & Mich(e)l Baycinouich & - & 252 \\
\hline Martin Semeljić & Martin Semeglich & 3 & 9 \\
\hline Andrija Stipičić & Andrea Stipicich & 2 & 133 \\
\hline Svećenik Vid Cvitić & p. Vido Cuitich & 4 & 227 \\
\hline Mihovil Bajčinović & Michel Baycinouich & - & 224 \\
\hline Marko Zorić & Marco Zorich & 1 & 177 \\
\hline Peko Trčimaz iz Komorana & Pecho Tarcimaz da Comorane & - & 327 \\
\hline Andrija Klarić & Andrea Clarich & - & 310 \\
\hline Lovre Cvitić & Lorenzo Cuitich & 1 & 20 \\
\hline Mate Semeljić & Mattio Semeglich & - & 279 \\
\hline Martin Budoić & Martin Budoich & 1 & 230 \\
\hline Vid Škarić & Vido Scarich & 1 & 30 \\
\hline Grgur Medoševac & Gregorio Medosauaz & - & 258 \\
\hline Grgur Medoševac & Il detto in alt(r)o loco & $\mathbf{4 7}$ & $\mathbf{1 6 5}$ \\
\hline Ukupno & & \\
\hline & & & \\
\hline
\end{tabular}

43 IT-ASVe-0450-SDC, pezzo 39, br. 5, fol. 3r.

44 Usp. Raukar, Zadar u XV. stoljeću, 180. 
U Petrčanima je samostan Sv. Marije posjedovao 8 ždrijebova, a obrađivali su ih sljedeći koloni: Juraj Lučić, Pavao Lisica, Andrija, zet Marka Rabčića, Mate Kajin, Franjo iz Lošinja, Ivan Ljubin, Mate iz Lošinja i Blaž Marčelin. Posjed u Petrčanima unajmili su 1562. - 1563. svećenici Ivan Barbiričić i Juraj Opančar za 100 dukata. ${ }^{45}$ Godine 1564. doznaje se da se na tom posjedu sijalo pšenicu, ječam, proso i bob (tablica 5). Za 8 ždrijebova zemljišta samostan je godišnje utrošio 3 mletačka stara i 1 kvartu pšenice za sjetvu. O uklanjanju korova sa zgona i ovdje su brigu vodile žene, $s$ istom cijenom rada od 4 solda po glavi. ${ }^{46}$

Tablica 5. Vrsta i količina prinosa žitarica sa samostanskoga posjeda u Petrčanima za 1564. godinu

\begin{tabular}{|l|r|c|}
\hline \multirow{2}{*}{ Vrsta žitarice } & \multicolumn{2}{c|}{ Količina } \\
\cline { 2 - 3 } & Stara & Kvarti \\
\hline Pšenica & 32 & 1 \\
\hline Ječam & 26 & - \\
\hline Proso & 3 & 1 \\
\hline Bob & 3 & - \\
\hline Ukupno & 137 & - \\
\hline
\end{tabular}

Osim kolona koji su obrađivali samostanske ždrijebove u izvorniku su navedeni obrađivači vinograda samostana Sv. Marije na posjedu u Petrčanima u drugoj polovini 16. stoljeća (tablica 6).

Tablica 6. Imena i prezimena kolona koji su obrađivali samostanske vinograde u Petrčanima, s naznačenom veličinom vinograda u gonjajima

\begin{tabular}{|l|l|c|}
\hline \multicolumn{2}{|c|}{ Kolon } & Gonjaja \\
\hline Ime i prezime & Izvornik & 4 \\
\hline Pavao Lisičin ${ }^{47}$ & Paulo Lissicin in loco detto Prisad & 3 3/4 \\
\hline Antun iz Lošinja & Ant(oni)o d(a) Lossign in doi pezzi in Dugazza & $41 / 2$ \\
\hline Andrija, zet Marka Rabčića & $\begin{array}{l}\text { And(re)a zenero d(el) Marco Rubcich in doi lochi in } \\
\text { Dugazza }\end{array}$ & 2 \\
\hline Ivan Ljibin & Zuane Glibin in dito loco & $2 \frac{11 / 4}{4}$ \\
\hline Mate Dragović & Mattio Dragouich in ditto loco & 2 \\
\hline Ante Devenešić & Ant(oni)o D(e)uenesich in ditto loco & \\
\hline Zaneto, zet Lasibaše & Zanetto zenero d(e) Lasibassa in ditto loco & \\
\hline
\end{tabular}

\footnotetext{
45 IT-ASVe-0450-SDC, pezzo 39, br. 5, fol. 3v.

${ }^{46}$ IT-ASVe-0450-SDC, pezzo 39, br. 5, fol. 4r.

${ }_{47}$ Vjerojatno je riječ o Pavlu Lisici, čije je prezime u izvorniku prvotno zapisano kao Lissiza, a potom Lissicin.
} 
Nastavak tablice 6.

\begin{tabular}{|c|c|c|}
\hline \multicolumn{2}{|r|}{ Kolon } & \multirow{2}{*}{ Gonjaja } \\
\hline Ime i prezime & Izvornik & \\
\hline $\begin{array}{l}\text { Šimun, zet Krnice, i } \\
\text { Sebastijan }\end{array}$ & Simo(n) zenero d(e) Carniza et Bastian in ditto loco & $1 \frac{1 / 2}{2}$ \\
\hline Toma Devenešić & Thomaso Deuenesich in Prisade & 3 \\
\hline Mate Dragović & Mattio Dragouich in ditto loco & 2 \\
\hline Jaša Kalafa ${ }^{48}$ & Jaxa Calafa in Dugazza & $1 \frac{1 / 2}{2}$ \\
\hline Juraj Lučić & Zorzi Lucich gastaldo in Peterzane & 5 \\
\hline Juraj Ljubljanin & Zorzi Gliubglianin Pri Uerbi & $1 \frac{1}{2}$ \\
\hline Ante Devenešić & Ant(oni)o Deuenesich in ditto loco & $1 \frac{1}{2}$ \\
\hline \multicolumn{2}{|l|}{ Ukupno } & $381 / 2$ \\
\hline
\end{tabular}

Na Bokanjcu je samostan Sv. Marije posjedovao 12 i pol gonjaja vinograda, a obrađivala su ih petorica kolona (tablica 7), koji su samostanu podavali četvrtinu prinosa, prema identičnom obrascu s vinograda na drugim posjedima, uz redovite naknade onima koji su samostanu dostavljali mošt. ${ }^{49}$

Tablica 7. Imena i prezimena kolona koji su obrađivali samostanske vinograde u Bokanjcu, s naznačenom veličinom vinograda u gonjajima

\begin{tabular}{|l|l|c|}
\hline \multicolumn{2}{|c|}{ Kolon } & \multirow{2}{*}{ Gonjaja } \\
\hline Ime i prezime & Izvornik & $3 \frac{1}{2}$ \\
\hline Ivan Stipačinović & Zuane Stipacinouich & $1 / 2$ \\
\hline Mate Gusarović & Mattio Gussarouich co(n) il nepote & $1 \frac{1}{2}$ \\
\hline Pavao Rataić & Paulo Rataijch & 1 \\
\hline Mate iz Vira & Mattio de Pontadura & 1 \\
\hline Pavao Rataić & Paulo Rataijch & $2 \frac{1}{2}$ \\
\hline Pavao Rataić & Item del ditto & $2 \frac{1}{2}$ \\
\hline Mate Lalić & Mattio Lalic(h) dal Borgo & $\mathbf{1 2 ~} \frac{1}{2}$ \\
\hline Ukupno & & \\
\hline
\end{tabular}

U Bibinjama je samostan Sv. Marije posjedovao pet ždrijebova co(n) li soi sedili, a taj zemljišni posjed uzeo je u najam zadarski plemić Jeronim Soppe uz godišnju rentu od približno 96 dukata. ${ }^{50}$ Vjerojatno je riječ o posjedu koji se nazivao i Tokinja, a samostanu ga je darovao kralj Petar Krešimir IV. ${ }^{51} \mathrm{Na}$ samostanskom posjedu u Bibinjama zemlju su obrađivali sljedeći koloni: Ivan Dorić, Andrija,

\footnotetext{
48 Nejasno je u ovom slučaju radi li se o prezimenu ili o oznaci zanimanja brodograditelja (kalafat).

49 Taj je iznos za razdoblje 1562. - 1564. iznosio 21 liru. IT-ASVe-0450-SDC, pezzo 39, br. 5, fol. 4v.

50 IT-ASVe-0450-SDC, pezzo 39, br. 5, fol. 5r.

51 Peričić, „Samostan sv. Marije”, 10.
} 
Skrijačićev zet, Ambrozije Varčić i njegov brat, Pavao Margitić i njegova braća te Mihovil Brzović, gastald. Zanimljivo je zamijetiti da su gastald Mihovil Brzović i Ambrozije Varčić zabilježeni tada kao stanovnici grada, u predjelu kovača, okupljenih oko crkve sv. Ivana Krstitelja u Zadru, ${ }^{52}$ a živjeli su u nekretninama u posjedu samostana Sv. Marije. Jednako je zabilježeno i za Vida Škaričića iz Opatica sela, koji je zaveden kao kolon i zakupnik samostanskih vinograda, a stanovao je u nekretnini u posjedu samostana Sv. Marije u Zadru u istom gradskom predjelu. ${ }^{53}$

Samostan Sv. Marije posjedovao je dva ždrijeba u selu Tršci (in Villa Tarsci) ${ }^{54} \mathrm{i}$ jedan ždrijeb u selu Miljacka (Villa Migliazcha). ${ }^{55}$ Ta su zemljišta dana u trogodišnji najam Inocentu Armaniju za 36 dukata. ${ }^{56}$ Usporede li se iznosi pojedinih najmova na godišnjoj odnosno trogodišnjoj razini, može se zaključiti da su kvaliteta zemljišta i količina prinosa bitno utjecale na određivanje najamne cijene.

Tri ždrijeba zemljišta nalazila su se u Novoselcima ${ }^{57}$, bila su iznajmljena svećeniku Grguru Meljkoviću (p. Gregorio Meglcouich) 1562. i 1563. godine za 20 lira, a naznačeno je da ih seljani nisu obrađivali (non senta nisun villan). Samostan je 1564. s toga posjeda uprihodio tek 1 star i 1 kvartu pšenice. U selu Čakavci (Chiachafci) samostan je posjedovao tri ždrijeba, koje je 1562. i 1563. unajmio Pavao iz Čakavaca za 28 lira. ${ }^{58}$ Sljedeće godine samostan je tu uprihodio 1 star i 2 kvarte pšenice, a jednako i ječma. U Krnčini (Charncina) samostan je posjedovao jedan ždrijeb, a unajmio ga je u razdoblju 1562. - 1564. Toma iz istoga sela za 39 lira. ${ }^{59} \mathrm{U}$ Galovcu (Galofci) prostiralo se pet samostanskih ždrijebova, a u Kamenjanima (Camegna$n e)$ dva. Te zemljišne posjede monahinje Sv. Marije dijelile su s monahinjama Sv. Dimitrija i Sv. Marcele u Zadru (proindiuise con le Reuerende monache de San Dimitri et de San Marcella). Ta je zemljišta 1562. i 1563. uzeo u najam samostanski prokurator i zadarski plemić Bernardin Galelli za 33 lire i 2 solda najamnine. U selu

52 O tome vidi više u: Pavuša Vežić, „Bazilika Sv. Ivana Krstitelja (Sv. Nediljica) u Zadru. Prilog poznavanju ranoromaničke arhitekture u Dalmaciji”, Radovi Instituta za povijest umjetnosti 23 (1999): 7-16.

53 IT-ASVe-0450-SDC, pezzo 39, br. 5, fol. 9v.

${ }^{54}$ Selo Tršci, koje je imalo crkvu sv. Bartula, nalazilo se u dijelu današnjega Galovca oko položaja Crkvina, gdje je bila spomenuta crkva. Anzulović, „Razgraničenje između mletačke i turske vlasti”, 94-95. Poznato je da su 1397. zadarske benediktinke Sv. Marije kupile za 1.800 denara dva ždrijeba zemlje u Tršcima od Maura Petrova Grisogona i Jurja Vida Zandulinova, pa je pretpostavka da se radi o istom zemljištu. Nikola Jakšić, Hrvatski srednjovjekovni krajobrazi (Split: Muzej hrvatskih arheoloških spomenika - Split, 2000), 219-220.

55 Miljacka se nalazila na području današnjega Zemunika. Anzulović, „Razgraničenje između mletačke i turske vlasti”, 82.

56 IT-ASVe-0450-SDC, pezzo 39, br. 5, fol. 5r.

57 Srednjovjekovno naselje Novoselci nalazilo se na mjestu današnjih Ninskih Stanova. Franjo Smiljanić, „Jesu li komunalne utvrde - stražice na zadarskom komunalnom kopnenom posjedu doista kasnoantičke?", Vjesnik Arheološkog muzeja u Zagrebu 43 (2010), br. 1: 400, bilj. 6.

58 O granicama sela Čakavci, koje su se protezale od sela Maljina do Ražanca, vidi: Anzulović, „Razgraničenje između mletačke i turske vlasti”, 78-79.

59 IT-ASVe-0450-SDC, pezzo 39, br. 5, fol. 5r. 
Račice (Racize) samostan je bio u najmu komada zemljišta veličine 15 gonjaja, za koji je godišnje plaćao 10 lira samostanu sv. Frane u Zadru. Prinosi toga zemljišta iznosili su 1 star i 2 kvarte pšenice te 4 stara i 3 kvarte maloga krupnika ${ }^{60} \mathrm{U}$ knjizi T. Raukara navodi se primjer u kojem se uobičajeno kmetsko podavanje pretvara u novčani zakup 1462. godine. ${ }^{61}$ Zanimljivo je da samostan Sv. Marije i sto godina poslije (1562.) iste posjede daje u zakup, odnosno s njih podiže novčanu rentu.

U Zatonu (Villa Zaton) samostan je s monahinjama Sv. Nikole i Sv. Dimitrija dijelio dva ždrijeba, koje su obrađivali baštinici pok. Mihe i Ante Bašića (quondam Miha Bassich et Antonio Bassich). S toga posjeda uprihođena su 4 mletačka stara žitarica (pšenica, ječam, krupnik i proso), a samostan je godišnje na njemu za sjetvu utrošio tek 3 mala kvartarola pšenice.

U izvorniku su zasebno naznačeni samostanski posjedi na kopnu u blizini granice osmanskoga teritorija (alli confini de Turchi), i to u naseljima Biljane i Pritičevci, Ambroza selu i Dolcu pokraj Novigrada. Samostan je imao posjed u Biljanima i Pritičevcima (Bigliane et Pritifcefci) sastavljen od 13 i pol ždrijebova. ${ }^{62} \mathrm{Uz}$ te posjede naznačeno je da ih obrađuje devet seljana (sopra la qual sentano contadini noue): Ivan Lalojević, Mate Brečevac, Mihovil Pinezić, Rade Šimunović, Helena, sestra Vinka Frletića, Petar Lalojević, Vid Suhalović, Petrica Pinezić i Vid Žužić. ${ }^{33}$ Jedan ždrijeb u Biljanima (Villa Bigliane) uzeo je u trogodišnji najam svećenik Vinko Frletić ( $p$. Vincenzo Ferletich) za 12 lira godišnje najamnine. ${ }^{64}$

U Ambroza selu (Ambrosa selo ${ }^{65}$ samostan je posjedovao sedam ždrijebova, a obrađivala su ih četvorica seljana: Bartolomej Sinošić, Juraj, sin Andrije Hlapčića, Petar Strparević i Antun Kršulović.

Ždrijeb zemljišta samostan Sv. Marije posjedovao je u Dolcu (in loco chiamato Dolaz) pokraj Novigrada, a obrađivao ga je Grgur Šprljić. ${ }^{66}$ Polovicu ždrijeba na tom posjedu dijelili su baštinici pok. Francesce Ferra iz Šibenika i fratri zadar-

${ }^{60}$ IT-ASVe-0450-SDC, pezzo 39, br. 5, fol. 5v.

${ }^{61}$ Godine 1462. kmet samostana Sv. Marije u Miljacki Tomaš Zloćud zakupljuje na pet godina samostanski ždrijeb u Miljacki na kojem sam sjedi (super qua residet dictus conductor), a usto i prihode sa ždrijeba u Tršcima i s još dva komada zemljišta u Galovcu i Račicama: umjesto kmetskoga podavanja sa ždrijeba u Miljacki samostanski kmet sada plaća samo godišnju zakupninu od 155 libara. Dok je Tomaš uzeo u zakup prihode samostanskoga zemljišta u Tršcima, Galovcu i Račicama, dotle je za ždrijeb u Miljacki napravljena prava komutacija naturalne u novčanu rentu. Raukar, Zadar u XV. stoljeću, 185.

${ }^{62}$ Biljane i Pritičevce osmanska strana trebala je vratiti mletačkoj 1550. godine. Anzulović, „Razgraničenje između mletačke i turske vlasti”, 101.

${ }^{63}$ IT-ASVe-0450-SDC, pezzo 39, br. 5, fol. 15v.

64 IT-ASVe-0450-SDC, pezzo 39, br. 5, fol. 5v.

${ }^{65}$ Ambroza selo ili Ambrozića selo nalazilo se na području današnjega Radovina. O granicama sela vidi više u: Anzulović, „Razgraničenje između mletačke i turske vlasti”, 81.

${ }^{66}$ Selo Dolac stajalo je sjeveroistočno od Pritičevaca. Anzulović, „Razgraničenje između mletačke i turske vlasti", 62 . 
skoga samostana sv. Dominika. S tih posjeda pristizale su neznatne količine pšenice, ječma, krupnika i prosa, ukupno oko 51 mletački star žitarica. ${ }^{67}$

U sklopu samostanskih kopnenih posjeda zasebno su naznačeni i oni smješteni na ninskome teritoriju u naselju Privlaka. Samostan Sv. Marije dijelio je polovinu od pet ždrijebova zemljišta u Privlaci sa samostanom sv. Dominika u Zadru, a druga polovina pripadala je zadarskom plemiću Zoilu de Ferra. U istom naselju samostan Sv. Marije dijelio je polovinu od dva ždrijeba sa zadarskim dominikancima, a druga polovina pripadala je plemiću Petru Karnarutiću. ${ }^{68} \mathrm{U}$ tri godine samostan je s posjeda na ninskome teritoriju uprihodio oko 5 mletačkih stara žitarica (pšenice, ječma, prosa i maloga krupnika). ${ }^{69}$

Sveukupno je samostan Sv. Marije u Zadru u razmatranom razdoblju posjedovao 98 ždrijebova zemlje na kopnenim posjedima te 173 gonjaja i 265 pertika vinograda. Udio ždrijebova zemlje na kopnu po pojedinim naseljima te broj kolona koji su ih obrađivali, odnosno najmitelja kojima su bili iznajmljeni tablično se prikazuje počevši od naselja s najvećim brojem ždrijebova prema onima s najmanjim brojem (tablica 8).

Tablica 8. Broj ždrijebova zemlje, kolona i najmitelja na kopnenim posjedima samostana Sv. Marije u Zadru izražen po pojedinim naseljima

\begin{tabular}{|l|c|c|c|}
\hline Naselje & Broj ždrijebova zemlje & Broj kolona & Broj najmitelja \\
\hline Stomorino selo & 22 & 21 & - \\
\hline Opatica selo & 18 & 15 & - \\
\hline Biljane i Pritičevci & 14,5 & 9 & 1 \\
\hline Petrčane & 8 & 8 & 2 \\
\hline Ambroza selo & 7 & 4 & - \\
\hline Bibinje & 5 & 6 & - \\
\hline Galovac & 5 & - & 1 \\
\hline Privlaka & 3,5 & - & 1 \\
\hline Novoselci & 3 & - & 1 \\
\hline Čakavci & 3 & - & - \\
\hline Zaton & 2 & 2 & 1 \\
\hline Kamenjani & 2 & - & - \\
\hline Tršci & 2 & - & 1 \\
\hline Dolac kod Novigrada & 1 & 1 & 1 \\
\hline Miljacka & 1 & - & $\mathbf{6}^{70}$ \\
\hline Krnčina & 1 & - & \\
\hline Sveukupno & $\mathbf{9 8}$ & & \\
\hline
\end{tabular}

\footnotetext{
${ }_{67}$ IT-ASVe-0450-SDC, pezzo 39, br. 5, fol. 15v.

68 Riječ je o bratu pjesnika Brne Karnarutića.

69 IT-ASVe-0450-SDC, pezzo 39, br. 5, fol. 16r.

70 Posjede u Galovcu i Kamenjanima uzeo je u najam isti najmitelj, a jednako je bilo s onima u Tršcima i Miljacki.
} 


\section{Posjedi u gradu i okolici}

U blizini grada prostirali su se uglavnom samostanski vinogradi i ponešto oranica, u granicama nekadašnje astareje, što je uostalom bila karakteristika i ostalih crkvenih institucija u Zadru. Na području Varoša samostan je uglavnom posjedovao vrtove, koji su davani u najam. ${ }^{71}$ Lokaliteti na kojima su se prostirala zemljišta u blizini grada spominju se i kod zemljišnih posjeda drugih crkvenih institucija u gradu ${ }^{72}$, a njihovo ubiciranje potanko je razradio Franjo Smiljanić. ${ }^{73}$ Tablično se prikazuju imena zadarskih težaka, njihov društveni status i podrijetlo ondje gdje je naznačeno te položaj, vrsta i veličina obrađivanih zemljišta izražena u gonjajima koja su bila u posjedu samostana Sv. Marije u Zadru u razdoblju 1562. - 1564. na tom području (tablica 9).

Tablica 9. Imena težaka, položaj, vrsta i veličina samostanskih zemljišta u gradu i okolici

\begin{tabular}{|l|l|c|c|}
\hline Težak & Položaj zemljišta & $\begin{array}{c}\text { Vrsta } \\
\text { zemljišta }\end{array}$ & $\begin{array}{c}\text { Površina } \\
\text { (gonjaji) }\end{array}$ \\
\hline Martin Bibigna & $\begin{array}{l}\text { Sjeverno od crkve Gospe Maslinske } \\
\text { (apresso la chiesa della Madonna } \\
\text { delle oliue da parte de tramontana) }\end{array}$ & vinograd & 2 \\
\hline Piero Lissicich & Sjeverno od crkve Gospe Maslinske & vinograd & 2 \\
\hline Luca Piua & In Valle d(e) Magistri picola & vinograd & 1 \\
\hline $\begin{array}{l}\text { Ser Alexandro da Bologna } \\
\text { zenero de Meser Lazaro da } \\
\text { Pontremolo }\end{array}$ & $\begin{array}{l}\text { Kod Gospe Maslinske (apresso la } \\
\text { Madonna delle oliue) }\end{array}$ & vinograd & $\begin{array}{c}7 \text { (obrađena } \\
\text { gonjaja) }\end{array}$ \\
\hline Piero Pastrouich & Kod Figurice (appresso Figuriza) & vinograd & 2 \\
\hline Zorzi Cimelich & Batalje (Battaglie) & vinograd & 2 \\
\hline Clara Calebichia & Batalje & vinograd & 2 \\
\hline Andrea Pagor & Pod Figuricom (sotto Figuriza) & vinograd & 2 \\
\hline Martin Bibigna dal Borgo & Pod Brdom (sotto Monte) & vinograd & 2 \\
\hline P. Mattio Mihaglich & Pod Brdom & vinograd & 4 \\
\hline Mare Petricichia & Pod Brdom & vinograd & 2 \\
\hline Simon Mircetta & Pod Brdom & vinograd & 2 \\
\hline Paulo Pissan & Pod Brdom & vinograd & 2 \\
\hline P. Zuane Barbich & Pod Ozrinjem (Pod Osrigne) & vinograd & 2 \\
\hline $\begin{array}{l}\text { Gregorio zenero de } \\
\text { Vlahouich }\end{array}$ & Pod Ozrinjem & vinograd & 3 \\
\hline
\end{tabular}

\footnotetext{
71 IT-ASVe-0450-SDC, pezzo 39, br. 5, fol. 6r-7v.

72 Usp. Lovorka Čoralić, „Zemljišni posjedi dominikanskog samostana u Zadru u XVII. i XVIII. stoljeću", Croatica Christiana periodica 18 (1994), br. 33: 215.

73 Franjo Smiljanić, „O položaju zadarskog posjeda Mons Ferreus”, Diadora 22 (2007): 281-300.

74 Riječ je o bogatome zadarskom trgovcu Lazaru de Gnochisu de Pontremolo. O njemu vidi više u: Raukar et al., Zadar pod mletačkom upravom, 259-260.
} 
Nastavak tablice 9.

\begin{tabular}{|c|c|c|c|}
\hline Težak & Položaj zemljišta & $\begin{array}{c}\text { Vrsta } \\
\text { zemljišta }\end{array}$ & $\begin{array}{r}\text { Površina } \\
\text { (gonjaji) }\end{array}$ \\
\hline Vido Giacofcich & Na Ozrinju (na Osrignu) & vinograd & $11 / 2$ \\
\hline- & Pod Gaženicom (sotto Gazenice) & $\begin{array}{l}\text { neobrađeno, } \\
\text { bez prinosa }\end{array}$ & 4 \\
\hline Vido Ostrouiza del Borgo & Klupine (Clupine) & \begin{tabular}{|l|} 
oranica \\
\end{tabular} & 2 \\
\hline Vido Ostrouiza del Borgo & Klupine & vinograd & 3 \\
\hline Antonio da Pago & Klupine & vinograd & $1 \frac{1}{2}$ \\
\hline $\begin{array}{l}\text { Ser Bartholomeo da } \\
\text { Rauena }\end{array}$ & Klupine & vinograd & 4 \\
\hline Mistro Mattio marangon & Klupine & vinograd & 3 \\
\hline $\begin{array}{l}\text { Reuerendo Meser p. Nicolo } \\
\text { Tressich }\end{array}$ & Klupine & vinograd & 3 \\
\hline $\begin{array}{l}\text { Mistro Vincenzo fiol de } \\
\text { Perina Calafa }\end{array}$ & Klupine & vinograd & $1 \frac{1 / 2}{2}$ \\
\hline Zorzi da Sibenico & Klupine & vinograd & 1 \\
\hline $\begin{array}{l}\text { Sorella del Meser p. Zuane } \\
\text { Fabio }\end{array}$ & Klupine & vinograd & 1 \\
\hline Antonio Chglissura & Klupine & vinograd & 3 \\
\hline $\begin{array}{l}\text { Simon et Michel fratelli } \\
\text { Rafnichi }\end{array}$ & Klupine & vinograd & 3 \\
\hline Simon Puiese & Klupine & vinograd & 6 \\
\hline $\begin{array}{l}\text { Mistro Antonio Vlaho } \\
\text { fauro }\end{array}$ & Klupine & vinograd & $1 \frac{1 / 2}{2}$ \\
\hline Magistro Giacomo calafa & Klupine & vinograd & 4 \\
\hline Vido fauro & Klupine & vinograd & 2 \\
\hline $\begin{array}{l}\text { Phillippo Tuartcouich } \\
\text { bazzariotto }\end{array}$ & Klupine & vinograd & 2 \\
\hline Zuane Puhof del Borco & $\begin{array}{l}\text { Kod Sv. Marka (appresso San } \\
\text { Marco) }\end{array}$ & vinograd & $1 \frac{1 / 2}{2}$ \\
\hline Gregor Grubacich & Iznad Sv. Ivana (sopra San Zuane) & oranica & 2 \\
\hline Piero Lissicich & Iznad Sv. Ivana & oranica & 2 \\
\hline Zuane fornaro & Iznad Sv. Ivana & oranica & 1 \\
\hline Zuane Paerouich & Iznad Sv. Ivana & oranica & 4 \\
\hline Vido de Stoia & Iznad Sv. Ivana & oranica & 5 \\
\hline Michel Despericich & Iznad Sv. Ivana & oranica & 5 \\
\hline Mara del Borgo & Iznad Sv. Ivana & oranica & 1 \\
\hline Giacomo Choscich & - & vinograd & 3 \\
\hline- & Artina & $\begin{array}{l}\text { sterilno } \\
\text { zemljište }\end{array}$ & 6 \\
\hline Zorzi Butrich & Artina & vinograd & 3 \\
\hline $\begin{array}{l}\text { Stephano Telletina del } \\
\text { Borgo }\end{array}$ & - & oranica & 3 \\
\hline
\end{tabular}


Nastavak tablice 9.

\begin{tabular}{|c|c|c|c|}
\hline Težak & Položaj zemljišta & $\begin{array}{c}\text { Vrsta } \\
\text { zemljišta }\end{array}$ & $\begin{array}{r}\text { Površina } \\
\text { (gonjaji) }\end{array}$ \\
\hline Gregorio Despericich & Soline (alle saline) & oranica & 6 \\
\hline- & $\begin{array}{l}\text { Kod varoških zidina (appresso le } \\
\text { mure del borgo) }\end{array}$ & $\begin{array}{c}\text { sterilno } \\
\text { zemljište }\end{array}$ & 4 \\
\hline $\begin{array}{l}\text { Mare fu fantesca de } \\
\text { Bartolacci }\end{array}$ & Kanali (Alli canali) & vinograd & 3 \\
\hline $\begin{array}{l}\text { Meser Francesco de } \\
\text { Treuiso }\end{array}$ & Kanali & vinograd & 2 \\
\hline Piero Chego del Borgo & Kanali & vinograd & 2 \\
\hline Fiola de Marchietouizza & Kanali & vinograd & 2 \\
\hline Fioli de Razdrich & Kanali & vinograd & 1 \\
\hline Simon Draghissin & Kanali & vinograd & 4 \\
\hline Ser Marco Biondo & Kanali & vinograd & 3 \\
\hline $\begin{array}{l}\text { Zorzi gastaldo delle } \\
\text { Reuerende Monache }\end{array}$ & Kanali & vinograd & $1 \frac{1 / 2}{2}$ \\
\hline- & Kanali & $\begin{array}{c}\text { sterilno } \\
\text { zemljište }\end{array}$ & 5 \\
\hline- & $\begin{array}{l}\text { Kod mlina u Kanalima (Alli canali } \\
\text { appresso il molin) }\end{array}$ & $\begin{array}{c}\text { sterilno } \\
\text { zemljište }\end{array}$ & 6 \\
\hline Gregorio da Scardona & Kanali & vinograd & 2 \\
\hline $\begin{array}{l}\text { Phillippo Martcouich } \\
\text { bazzariotto }\end{array}$ & Kanali & vinograd & 2 \\
\hline Mistro Zorzi stagner & Kanali & vinograd & 2 \\
\hline Mistro Gregorio fauro & Kanali & vinograd & 4 \\
\hline $\begin{array}{l}\text { Reuerendissimo p. Zorzi } \\
\text { Barzotto }\end{array}$ & Kanali & vinograd & 2 \\
\hline P. Paulo del Borgo & Kanali & vinograd & 2 \\
\hline $\begin{array}{l}\text { Mistro Piero Trifunich } \\
\text { marangon }\end{array}$ & Kanali & vinograd & 2 \\
\hline Rado del Castel nouo & Kanali & vinograd & 2 \\
\hline $\begin{array}{l}\text { Donna Gasparina } \\
\text { Rahonichia }\end{array}$ & Kanali & vinograd & 4 \\
\hline Zorzi Balabanchin & Kanali & vinograd & 3 \\
\hline $\begin{array}{l}\text { Mistro Gregorio } \\
\text { Stoimilouich marangon }\end{array}$ & Kanali & vinograd & 1 \\
\hline Giacomo mariner & Kanali & vinograd & 1 \\
\hline Zorzi Messodiglich & Kanali & vinograd & $3 / 4$ \\
\hline Helena Vrancha & Crno (uigne a Cerno) & vinograd & 3 \\
\hline Piero Sladich & Crno & vinograd & 3 \\
\hline Giacomo Vuchof & Crno & vinograd & 3 \\
\hline Hieronymo Brigocich & Crno & vinograd & 2 \\
\hline Hieronymo Brigocich & Crno & oranica & 4 \\
\hline
\end{tabular}




\begin{tabular}{|c|c|c|c|}
\hline Težak & Položaj zemljišta & $\begin{array}{c}\text { Vrsta } \\
\text { zemljišta } \\
\end{array}$ & $\begin{array}{l}\text { Površina } \\
\text { (gonjaji) }\end{array}$ \\
\hline $\begin{array}{l}\text { Zorzi gastaldo delle } \\
\text { Reuerende Monache }\end{array}$ & Smiljevac (in Smiglieuaz) & oranica & 4 \\
\hline $\begin{array}{l}\text { Helesabeth r. q. mistro } \\
\text { Zuane boter }\end{array}$ & Smiljevac & oranica & 2 \\
\hline Zorzi Carglien & Smiljevac & oranica & 2 \\
\hline Stephano Mozanich & In Hrigor (Klikor?) ${ }^{75}$ & oranica & $1 \frac{1 / 2}{2}$ \\
\hline $\begin{array}{l}\text { Proindiuiso con S. Dimitri } \\
\text { et S. Marcella }\end{array}$ & Ozrinje & $\begin{array}{c}\text { sterilno } \\
\text { zemljište }\end{array}$ & 4 \\
\hline Ser Giacomo Salamonich & Sotto Belueder & oranica & $1 \frac{1 / 2}{2}$ \\
\hline $\begin{array}{l}\text { Zorzi gastaldo delle } \\
\text { Reuerende Monache }\end{array}$ & Paprat (in Paprat) & vinograd & $1 \frac{1 / 2}{2}$ \\
\hline Simon Possilouich & Paprat & vinograd & 3 \\
\hline $\begin{array}{l}\text { Zorzi gastaldo delle } \\
\text { Reuerende Monache }\end{array}$ & Paprat & vinograd & 2 \\
\hline Mattio caualaro & Paprat & vinograd & 1 \\
\hline Gregorio Francouich & Paprat & vinograd & 2 \\
\hline Marco Roijsich & Paprat & vinograd & 4 \\
\hline P. Zorzi Millcih & Paprat & vinograd & 2 \\
\hline Zorzi fornaro & Paprat & vinograd & $2 \frac{1 / 2}{2}$ \\
\hline Michel Despericich & Paprat & vinograd & 2 \\
\hline Mistro Perina calafa & Paprat & vinograd & $1 \frac{1 / 2}{2}$ \\
\hline Simon Vlaho & Paprat & vinograd & 2 \\
\hline
\end{tabular}

Uz ta zemljišta samostan Sv. Marije posjedovao je na lokalitetu Kanali (alli canali $)^{76}$ dva mlina za mljevenje žitarica, od kojih je od 1562. do 1564. uprihodovano 460 lira, dok je 176 lira i 2 solda utrošeno u njihovo redovno održavanje (in concier de ditti molini masine magistre tauole chioldi et altro)..$^{77} \mathrm{Od}$ oranica $\mathrm{u}$ gradskom okruženju samostan je u tri godine uprihodio 10 stara ječma, 8 stara i 2 kvarte boba te 12 stara i 2 kvarte pšenice. Od vinograda je u tri godine uprihodovan 251 modij ili 10542 litara vina. Samostan Sv. Marije dijelio je sa samostanom sv. Dominika u Zadru neke pašnjake u Crnom, koji su dani u trogodišnji najam za 60 lira. ${ }^{78}$

\footnotetext{
75 Vjerojatno je riječ o lokalitetu Chricor, koji odgovara sačuvanome nazivu današnjega bunara Klikor, sjeveroistočno od ruševina crkve sv. Ciprijana nedaleko od Bokanjca. Nekada su se sjeveroistočno i jugoistočno od crkve sv. Ciprijana prostirali posjedi plemićke obitelji Varikaša. Smiljanić, „O položaju zadarskog posjeda Mons Ferreus", 289.

${ }^{76}$ Ivna Anzulović ubicirala je lokalitet Kanali južno od Musapstana i jugoistočno od Jadranske magistrale, na području sela Crno. Anzulović, „Razgraničenje između mletačke i turske vlasti”, 91.

77 IT-ASVe-0450-SDC, pezzo 39, br. 5, fol. 7r.

78 IT-ASVe-0450-SDC, pezzo 39, br. 5, fol. 7v.
} 


\section{Otočni posjedi}

Samostan Sv. Marije posjedovao je različita zemljišta i na zadarskim otocima. Dva ždrijeba zemljišta u vlasništvu samostana bila su na otoku Pašmanu. Dijelom su to bile oranice, a dijelom vinogradi, koje je obrađivao Ivan Skarabelić (Zuane Scarabelich).$^{79}$ Tablično se prikazuju vrste i količina prinosa žitarica s toga posjeda (tablica 10).

Tablica 10. Vrsta i količina prinosa žitarica sa samostanskoga posjeda na Pašmanu za razdoblje 1562. - 1564. godine

\begin{tabular}{|l|c|c|c|c|c|c|c|c|}
\hline \multirow{2}{*}{ Vrsta žitarice } & \multicolumn{2}{|c|}{1562.} & \multicolumn{2}{c|}{1563.} & \multicolumn{2}{c|}{1564.} & \multicolumn{2}{c|}{ Ukupno } \\
\cline { 2 - 9 } & Stara & Kvarti & Stara & Kvarti & Stara & Kvarti & Stara & Kvarti \\
\hline Pšenica & 7 & - & 10 & - & 3 & - & $\mathbf{2 0}$ & - \\
\hline Ječam & 16 & - & 17 & - & 10 & - & $\mathbf{4 3}$ & - \\
\hline Proso & - & - & 3 & 2 & - & - & $\mathbf{3}$ & $\mathbf{2}$ \\
\hline Bob & 2 & - & 3 & 2 & 3 & - & $\mathbf{8}$ & $\mathbf{2}$ \\
\hline
\end{tabular}

Glavninu samostanskih prihoda sa zadarskih otoka činila je stoka sitnoga zuba. U Luci (Valle de San Stephano) na Dugom otoku prostirali su se samostanska šuma i pašnjaci, uz ponešto vinograda. Za razliku od kopnenih, za otočne posjede u izvornicima nažalost nisu navedene pojedinačne parcele niti su naznačeni obrađivači vinograda. Samostan je 1562. posjedovao stočni fond od 345 glava (cauedal de caui) stoke sitnoga zuba (ovaca i koza). Sljedeće godine broj se povećao na 385 glava, a 1564. iznosio je 390 glava. I na Ižu se nalazio stočni fond samostana Sv. Marije, koji je 1562. činilo 345 glava stoke sitnoga zuba, 1563. godine 389 glava, a 1564. godine 394 glave. ${ }^{80}$

Okosnicu prihoda s otočnih posjeda činila je proizvodnja sira i vune te prodaja jarića i janjadi ${ }^{81}$ Sir se pravio tri puta godišnje. Prvi prinosi sira su se prodavali. Od 1562. do 1564. od prodaje sira iz Luke i Iža samostan je uprihodio 953 lire. Drugi i treći prinos sira išao je za samostanske potrebe. Od prodaje jarića i janjadi uprihodovana je 81 lira. Zapisano je da su prodavani po cijeni od 3 lire po glavi, što bi značilo da je samostan prodao 27 glava stoke sitnoga zuba. Ostatak se čuvao za potrebe samostana. Vuna se nije prodavala, nego se zadržavala isključivo za samostanske potrebe. ${ }^{82}$

\footnotetext{
79 IT-ASVe-0450-SDC, pezzo 39, br. 5, fol. 13r.

${ }^{80}$ Količina stoke ovisi o mogućnosti paše. Samostani i imućniji slojevi gradskoga pučanstva posjedovali su velika stada jer su raspolagali prostranim pašnjacima, bilo vlastitim bilo zakupljenim. Raukar, Zadar u XV. stoljeću, 198.

81 Usp. Raukar, Zadar u XV. stoljeću, 203.

82 IT-ASVe-0450-SDC, pezzo 39, br. 5, fol. 13r.
} 
Otočni zemljišni posjedi samostana Sv. Marije bili su znatno manjega opsega od onih na kopnenom dijelu zadarskoga okružja, što je razumljivo zbog manjega broja obradivih površina na zadarskim otocima. Samostan je posjedovao pola ždrijeba zemljišta u Banju na Pašmanu, dijelom pod vinogradom, dijelom pod oranicom, a obrađivao ga je Martin Kovačić (Chouacich) iz Banja. Prinosi toga posjeda iznosili su oko 6 stara žitarica. U Preku (Isola di San Michel) nalazio se jedan ždrijeb zemlje što ga je držao Grgur Grdović (Ghardouich), a bio je iznajmljen komisarima ser Šimuna Grisogona za 45 lira godišnje. U mjestu Ugljan na istoimenom otoku samostan je posjedovao ždrijeb zemljišta, na kojem je Mate Matijčić (Mattio Matijcich) sijao pšenicu i ječam, a prinosi su iznosili 7 stara žitarica. Na otoku Pagu samostan je posjedovao solane, koje je dao u najam Antunu Ramaničiću (Antonio Ramanicich) iz Paga za 10 dukata godišnje, odnosno 62 lire. ${ }^{83}$

\section{Nekretnine, liveli i novčano poslovanje}

\section{Gradske nekretnine u najmu}

Samostan Sv. Marije posjedovao je u Zadru 36 nekretnina koje su dane u najam. ${ }^{84}$ Godišnji najam za pojedinu nekretninu bio je od 6 do 62 lire, ovisno o njezinu položaju, veličini i kvaliteti. Riječ je isključivo o kućama u posjedu samostana Sv. Marije, osim jedne koju je dijelio sa samostanima sv. Nikole i sv. Dimitrija u Zadru, u kojoj je stanovao zadarski plemić Ludovik Nassi, a plaćao je godišnju najamninu u iznosu od 100 lira, od čega je jedna trećina pripadala benediktinkama Sv. Marije u Zadru. ${ }^{85}$ Glavnina nekretnina bila je smještena neposredno uz samostan i crkvu Sv. Marije u Zadru. Društvena struktura najmitelja bila je raznovrsna i obuhvaćala je pripadnike gotovo svih gradskih staleža i zanimanja, kao i doseljenike. Sveukupno je od najamnine gradskih nekretnina samostan na godišnjoj razini uprihodio 515 lira i 14 soldi. Samostan je redovito o vlastitom trošku održavao gradske nekretnine u svojem posjedu, o čemu svjedoče upisi o iznosu novca uloženog u njihovu obnovu (in concier). Godišnji troškovi održavanja gradskih nekretnina iznosili su u razmatranom razdoblju 335 lira i 8 soldi, odnosno oko $65 \%$ ukupnih godišnjih prihoda od najma.

\section{Zakupi (livelli) u gradu i Varošu}

Osim najma, samostan je na godišnjoj razini ubirao zakupninu (livello) za razne nekretnine u samome gradu i njegovu Varošu (Borgo). ${ }^{86} \mathrm{U}$ gradu je samostan

\footnotetext{
${ }_{83}$ IT-ASVe-0450-SDC, pezzo 39, br. 5, fol. 14r.

${ }^{84}$ IT-ASVe-0450-SDC, pezzo 39, br. 5, fol. 8r-10r.

${ }_{85}$ IT-ASVe-0450-SDC, pezzo 39, br. 5, fol. 10r.

${ }^{86}$ Marco Ferro opisuje zakup zemljišta ( fondo), kuća i drugih nekretnina pojedinaca koji, da bi uživali posjed, plaćaju vlasniku (livellatore) naknadu proporcionalno prihodovnoj vrijednosti nekretni-
} 
uživao prihode od 26 livela, a iz Varoša od 31 livela. Očito je da su prihodi od livela bili znatno niži od izravnoga najma te nisu prelazili iznos od 10 lira godišnje. ${ }^{87}$ Nadalje, kada je u pitanju izravni najam samostanskih nekretnina, radilo se isključivo o kućama odnosno stambenim zgradama, a u slučaju livela bilježe se raznovrsne nekretnine: kuće, dvorišta, zidine, vrtovi, podrumi i sl.

Zbog vrijednosti izvornoga gradiva za proučavanje zadarske povijesne antroponimije 16. stoljeća, a poštujući zakonitosti moderne egdotike, u prilogu rada donosi se cjelovit prijepis gradskih nekretnina u posjedu samostana Sv. Marije i njihovih najmitelja, kao i zakupnika koji su samostanu plaćali livel (prilozi 1 i 2).

\section{Troškovi samostana Sv. Marije u Zadru (1562. - 1564.)}

U izvješću samostanskoga zastupnika naznačeni su troškovi koje je samostan Sv. Marije u Zadru imao u tom razdoblju. Samostan se tada skrbio o materijalnim potrebama 66 pojedinaca. U to su spadale monahinje (monache uellade), djevojke $\left(_{\text {pute }}\right)^{88}$, picokare (pizzochare) ${ }^{89}$, posluga (fameio) te gastald ili dvornik samostana sa svojom obitelji (gastaldo con sua fameia). ${ }^{90}$ Iako u izvješću nije taksativno naveden broj koludrica u samostanu, prije 1570 . u njemu je bilo 36 sestara..$^{91}$

Od 1562. do 1564. samostan je za prehranu 66 usta (bocche) i ostale potrebe trošio kako slijedi:

- 792 mletačka stara pšenice (4 stara po glavi na godišnjoj razini)

- 1625 modija vina

ne. Takav oblik zakupa naziva se depozitarni zakup (livello consegnativo), u kojemu pravo služnosti nad nekretninom pripada zakupljivaču (livellario), koji se ugovorno obvezuje podmiriti troškove zakupljene nekretnine, a pritom je slobodan pravo služnosti prenijeti na drugu osobu, dok nekretnina i dalje pravno ostaje u rukama vlasnika. Usp. Marco Ferro, Dizionario del diritto comune e veneto, sv. II (Venecija: Andrea Santini e figlio, 1847), 202-203.

${ }^{87}$ IT-ASVe-0450-SDC, pezzo 39, br. 5, fol. 10r-12v.

${ }_{88}$ Pod samostanskim krovom živjele su i djevojke koje su se tamo učile i odgajale. Tijekom apostolske vizitacije 1579., zbog slabih prihoda samostana, vizitator Valier zabranio je sestrama da odgajaju i poučavaju djevojke, što je poslije opozvao. Jednako je 1603. apostolski vizitator Priuli zbog teškoga ekonomskog stanja naredio da ne smiju unaprijed držati djevojke ako im za to njihovi roditelji ne budu nadoknadili troškove. Filipi, „Samostan i crkva Sv. Marije”, 239. O odgoju djevojaka u ženskim samostanima u Zadru, s posebnim osvrtom na samostan Sv. Marije, vidi opširnije: Filipi, „Samostan i crkva Sv. Marije”, 256-260.

89 Zasebna vrsta stanovnica u ženskim samostanima bile su oblatae ili picokare. Obećavale su posluh opatici, nosile su djelomično redovničku odjeću i besplatno služile, ali su mogle lakše istupiti iz zajednice, a i samostan ih je mogao jednostavnije otpustiti. Ivan Ostojić, Benediktinci u Hrvatskoj i ostalim našim krajevima, sv. I (Split: Benediktinski priorat - Tkon, 1963), 132.

90 IT-ASVe-0450-SDC, pezzo 39, br. 5, fol. 14v.

91 Filipi, „Samostan i crkva Sv. Marije”, 239. 
- za potrebe prehrane radnika (companadego) pri obradi zemljišta, sjetvi, žetvi i berbi grožđa 600 lira

- ulje za rasvjetu samostana i crkve Sv. Marije (bocca lume, luminarii et per le lampade della chiesa) 60 modija

- drvo i ugljen za ogrjev (per legne et carbon) 75 lira

- za mljevenje žitarica 232 lire i 12 soldi

- za troškove održavanja pet mlinova za ulje i meljavu maslina 78 lira

- svijeće za crkvu i samostan 600 libara

- za bolesnike i pogrebne obrede 100 dukata

- troškovi apotekara (spicier) 357 lira i 4 solda

- za tamjan i mirtu (mira) 6 lira.

Pastirima na otočnim posjedima u Luci i na Ižu podavao se o Božiću kruh u vidu regalie, za što je utrošen 1 mletački star i 2 kvarte pšenice. Za svijeće i ostale potrebe pastira utrošene su 2 lire. Pastirima se podavalo 2 modija vina i pola stara ječmenoga brašna. Onima koji su pomagali pastirima u vrijeme proizvodnje sira i šišanja vune podavalo se 2 modija vina i kruh u iznosu od 1 stara pšenice, a za ostale potrebe utrošeno je 10 lira. ${ }^{92}$

Samostan je kapelanima za održavanje misa o godišnjicama smrti samostanskih darovatelja plaćao 365 lira i 2 solda. ${ }^{93}$ Samostanski pisar za svoju je službu na godišnjoj razini dobivao 6 stara pšenice, 6 stara ječma, 3 stara prosa, 2 kvarte boba, 3 dekalatra sira (calatri de formazo ${ }^{94}, 3$ starića ulja te 20 lira u novcu.

Samostan je svake godine bio dužan dati gastaldu ili dvorniku dvije košulje (doi camisse), dvije dolame od crne raše (doi dolimani de rassa negra), dva vunena šešira (doi capelli de lana), dva para čarapa (doi paro de calcetta), jedan par hlača od raše (uno paro de braghese de rassa), jedne hlače od tele (braghese di tella) i četiri para cipela (quattro pera de scarpe). Samostanskom sluzi godišnje se podavalo un calacro de lana, un capello de lana, un caban de rassa, sei pera de opanche. ${ }^{95}$

\footnotetext{
92 IT-ASVe-0450-SDC, pezzo 39, br. 5, fol. 14v.

${ }_{93}$ Novac je samostanu pristizao od pojedinaca i gradskih bratovština za aniverzarije (godišnje spomene umrlih). Tako je bratovština sv. Jakova plaćala godišnje 24 lire za nekoliko aniverzarija. Plemićka obitelj Civalelli plaćala je 6 lira, a isti iznos za tu svrhu davali su samostanu ser Vincenzo Bon za plemićku obitelj Galelli i vikar zadarskoga nadbiskupa Ivan Benja. Plemkinja Marketa Pećar (Madonna Marchetta de Pechiari) plaćala je 5 lira za aniverzarije, a svećenička bratovština Gospe od Milosrđa u crkvi sv. Stjepana (La fradaia della Madonna a San Stephano) 3 lire godišnje u istu svrhu. IT-ASVe0450-SDC, pezzo 39, br. 5, fol. 14r.

94 Čini se da dekalatar ili kalatar označava veći uteg (pondus grossum) koji je u pojedinim gradovima mogao imati različitu težinu. Sir se izrađivao u obliku koluta određenim gradskim kalupom. Usp. Kolanović, „Šibenski metrološki sustav u XV. stoljeću”, 196-197; Sabine Florence Fabijanec, „Od tržnice do luke. Trgovačka svakodnevica kasnoga srednjeg vijeka”, Kolo: časopis Matice hrvatske 16 (2006), br. 4: 195.

95 IT-ASVe-0450-SDC, pezzo 39, br. 5, fol. 15r.
} 
K tome je za obnovu samostana utrošeno 50 dukata i više, a zabilježeno je i loše stanje crkvenoga zvonika, koji je zahtijevao hitnu obnovu. ${ }^{96}$ Nije poznato je li i kada zvonik u 16. stoljeću obnovljen, ali je iz izvješća svakako očita hitnost toga posla jer je navedeno da će sve postati ruševina ako se reparacija ubrzo ne obavi (che manazano ruina se presto non si reparano). ${ }^{97}$

Završni dio izvješća svjedočanstvo je o materijalnim poteškoćama u samostanu Sv. Marije u drugoj polovini 16. stoljeća. Jasno je navedeno da je samostan bio obvezan pobrinuti se za odjeću redovnica ${ }^{98}$, ali se zbog slabih prihoda oslanjalo na pomoć rodbine i za odijevanje i za hranu. ${ }^{99}$

\section{Zaključak}

Na temelju službenoga izvješća zastupnika samostana Sv. Marije u Zadru za razdoblje 1562. - 1564. godine stekao se uvid u posjede koje su uživale zadarske benediktinke u drugoj polovini 16. stoljeća. Vidljivo je da je na širem zadarskom području u razmatranom razdoblju zadržana gotovo identična strukturna podjela zemljoposjeda kao i tijekom 15. stoljeća, a nisu se znatnije mijenjali ni agrarni odnosi na relaciji zemljoposjednik - kmet. Broj posjeda uglavnom je ostao na razini s početka 16. stoljeća, s tek neznatnim odstupanjima. Tradicionalna struktura kolonatskih ugovora sačuvala se i u vrijeme mletačko-osmanskih ratova. Posjedi samostana Sv. Marije na kopnenom dijelu zadarskoga okružja prostorno su bili smješteni na istim lokacijama, ali je zamjetno da su alodijalna zemljišta na pojedinim posjedima u drugoj polovini 16 . stoljeća bila umanjena u odnosu na primjerice 15. stoljeće. Reducirali su se i samostanski prihodi, na što su u prvom redu utjecali osmanski upadi na područje zadarskoga distrikta. S obzirom na to da je okosnicu gospodarskoga poslovanja samostana Sv. Marije činio zemljoposjed, od kojega se očekivao najveći prihod, nepovoljne društveno-političke okolnosti redovito su utjecale na proizvodni proces, a posljedično i na svakodnevni život koludrica u samostanu. Unatoč relativno velikom broju posjeda u vlasništvu samostana Sv. Marije u Zadru u drugoj polovini 16. stoljeća, godišnji prihodi nisu bili dovoljni za redovito pokrivanje svih samostanskih troškova, o čemu svjedoče i drugi izvori, primjerice izvješća apostolskih vizitacija iz 1579. i 1603. ili ona ad limina zadarskih nadbiskupa.

\footnotetext{
${ }_{96}$ O zvoniku vidi u: Pavuša Vežić, „Zvonik i kapitularna dvorana Samostana Sv. Marije Male u Zadru: kraljevska kapela - kapitul - sakristija - memorija”, u: Laude nitens multa. Zbornik radova s kolokvija u povodu 900. obljetnice Vekenegina epitafa, ur. Pavuša Vežić i Ivan Josipović (Zadar: Sveučilište u Zadru, 2018), 95-141.

97 IT-ASVe-0450-SDC, pezzo 39, br. 5, fol. 16r.

98 Usp. Filipi, „Samostan i crkva Sv. Marije”, 242-243.

99 IT-ASVe-0450-SDC, pezzo 39, br. 5, fol. 16r.
} 
Prilog 1. Prijepis samostanskih nekretnina samostana Sv. Marije u Zadru s naznačenim najmiteljima i visinom najma. Izvor: IT-ASVe-0450-SDC, pezzo 39, fol. 8r-10r.

(fol. 8r) Beni stabili in la città che pagano fitto alle R(euerende) Monache

$\mathrm{N}$ (umero) 1 Vna casa $\mathrm{p}(\mathrm{er})$ mezo la chiesa d(e) S(an)ta Maria in la q(u)al habita m(adonn)a Orsa fiola del q(uondam) m(eser) Simon Boyco paga d(el) fito ducati X. all'an(n)o lire 62 soldi -

Item fo speso in concier d(ella) dita casa lire 6 soldi 2

2 Vna casa p(er) mezo el graner del monasterio d(e) S(an)ta Maria in la qual habitano l'h(e)r(e)di del q(uondam) m(ist)ro Giacomo da Obrouazzo pillicer paga all'an(n)o lire 22 soldi -

Item fo speso in co(n)cier $\mathrm{d}(\mathrm{e})$ ditta lire 11 soldi -

3 Vna casa apresso la ditta in la $\mathrm{q}(\mathrm{u}) \mathrm{al}$ habita m(adonn)a Baldessera Grisogoni paga all'an(n)o lire 30 soldi -

Item fo speso in co(n)cier d(e) ditta lire 10 soldi -

4 Vna casa $\mathrm{p}(\mathrm{er})$ mezo il grener del monasterio contigua alla ditta in la $\mathrm{q}(\mathrm{u}) \mathrm{al}$ habita Franc(esc)o Poncie pillicer paga d(el) fito a lire 12 all'an(n)o ual lire 12 soldi Item fo speso in co(n)cier $\mathrm{d}(\mathrm{e})$ ditta lire 2 soldi -

5 Vna casa in co(n)fin d(e) S(anta) Maria in la q(u)al habita Isabetta r(elicta) q(uondam) $\mathrm{m}$ (ist)ro Zuanne buter paga d(el) fito ogni an(n)o lire 12 soldi -

Item fo speso in concier $\mathrm{d}(\mathrm{e})$ ditta lire 12 soldi 15 1/2

6 Vna casa in co(n)fin ut s(upr)a in la q(u)al habita Marg(ari)ta r(elicta) q(uondam) Franc(esc)o Petricich paga d(el) fito ogni anno lire 8 soldi 10 ual lire 8 soldi 10

Item fo speso in concier de ditta lire 4 soldi 12

7 Vna casa in co(n)fin ut s(upr)a in la corte p(er) mezo il granaro in la $q(u) a l$ habita Marco bicher da Sibenico paga d(e) fitto lire 10 all'an(n)o ual lire 10 soldi Item fo speso $\mathrm{p}(\mathrm{er}) \mathrm{co}(\mathrm{n})$ cier $\mathrm{d}(\mathrm{e})$ ditta lire 3 soldi -

(fol. 8v) 8 Vna casa posta in co(n)fin d(e) S(anta) Maria in canisela p(er) mezo la casa del q(uondam) m(eser) Franc(esc)o Thomaseo paga d(e) fito lire 8 all'an(n)o ual lire 8 soldi -

Item fo speso in concier $\mathrm{d}(\mathrm{e})$ ditta lire 4 soldi - 
9 Vna casa posta in co(n)fin ut s(upr)a p(er) mezo la casa d(el) p(rete) Marco Zagorcich paga $\mathrm{d}(\mathrm{e})$ fito lire 14 all'anno ual lire 14 soldi -

Item fo speso $\mathrm{p}(\mathrm{er})$ concier $\mathrm{d}(\mathrm{e})$ ditta lire 10 soldi -

10 Vna casa posta apresso mangano in la qual habita Vido Iuan $\mathrm{d}(\mathrm{e})$ Racize paga lire 6 soldi - all'anno d(e) fito ual lire 6 soldi -

Item fo speso in concier de ditta lire 2 soldi 8

11 Vna casa posta ut $\mathrm{s}(\mathrm{upr}) \mathrm{a}$ in la $\mathrm{q}(\mathrm{u})$ al habita Vicenzo Brazanin paga d(e) fito ogni an(n)o lire 6 soldi -

Item fo speso in concier $\mathrm{d}(\mathrm{e})$ ditta lire 2 soldi -

12 Vna casa posta ut $\mathrm{s}(\mathrm{upr}) \mathrm{a}$ in la $\mathrm{q}(\mathrm{u})$ al habita Zuan(n)e pescador paga d(e) fito ogni anno lire 6 soldi -

Item fo speso in concier $\mathrm{d}(\mathrm{e})$ ditta lire 2 soldi -

13 Vna casa posta ap(re)sso mangano in la q(u)al habita Nicolo Malacesa paga $\mathrm{d}(\mathrm{e})$ fitto ogni anno lire 5 soldi -

Item fo speso in concier $\mathrm{d}(\mathrm{e})$ ditta lire 1 soldi 4

14 Vna casa posta ap(re)sso Capeliza in la $\mathrm{q}(\mathrm{u})$ al habita Batista barbier q(uondam) Lorenzo paga ogni an(n)o d(e) fito lire 18 ual lire 18 soldi -

Item fo speso in concier $\mathrm{d}(\mathrm{e})$ ditta lire 108 soldi -

15 Vna casa posta ap(re)sso Capelliza in la q(u)al habita Thomaso Verceuich paga $\mathrm{d}(\mathrm{e})$ fitto ogni anno lire 8 soldi - ual lire 8 soldi -

Item fo speso in co(n)cier $\mathrm{d}(\mathrm{e})$ ditta lire 1 soldi 16

16 Vna casa posta ap(re)sso il uolto d(e) Gladouich in la q(u)al habitano l'h(e) r(e)di del q(uondam) Thomaso Crechich calegaro paga de fito ogni anno lire 25 soldi -

(fol. 9r) 17 Vna casa posta in confin d(e) S(an) Sylu(est)ro in la qual habita s(er) Zan Logotenente Stradiotto paga d(e) fitto ogni anno lire 15 soldi - ual lire 15 soldi -

Item fo speso in co(n)cier $\mathrm{d}(\mathrm{e})$ ditta lire 10 soldi 16

18 Vna casa posta per mezzo la casa del q(uondam) Bernardin Ballabanouich paga $\mathrm{d}(\mathrm{e})$ fito ogni anno lire 11 in la $\mathrm{q}(\mathrm{u})$ al habita Pietro Boccan bicher ual lire 11 soldi -

Item fo speso in co(n)cier $\mathrm{d}(\mathrm{e})$ ditta lire 7 soldi 14

19 Vna casa posta p(er) mezo S(an) Sylu(est)ro in la qual habita el h(e)r(e)de del q(uondam) Nic(ol)o fiol d(e) s(er) Alex(andr)o Nazaro ouer Chochari paga ogni anno d(e) fitto lire 22 soldi - ual lire 20 soldi - 
Item fo speso in co(n)cier $\mathrm{d}(\mathrm{e})$ ditta lire 12 soldi 6

20 Vna casa posta $\mathrm{p}(\mathrm{er})$ mezo S(an) Sylu(est)ro in la q(u)al habita m(ist)ro Sabastian da Taranto paga d(e) fitto ogni anno lire 20 soldi - ual lire 20 soldi -

Item fo speso in co(n)cier $\mathrm{d}(\mathrm{e})$ ditta lire 8 soldi -

21 Vna casa posta infra l'hostarie in la $\mathrm{q}(\mathrm{u})$ al habita s(er) Batt(ist)a Feltrin hosto paga $\mathrm{d}(\mathrm{e})$ fito ogni anno lire 40 soldi - ual lire 40 soldi -

Item fo speso in concier $\mathrm{d}(\mathrm{e})$ ditta lire 60 soldi -

22 Vna casa posta sop(ra) la Strada grande p(er) mezo la casa d(el) m(eser) Pietro Gliubauazo in la qual habita Iuan q(uondam) Mihouil Bolcich paga d(e) fitto ogni anno lire 8 soldi - ual lire 8 soldi -

Item fo speso in concier $\mathrm{d}(\mathrm{e})$ ditta lire 6 soldi 8

23 Vna casa alla Strada grande p(er) mezo la casa d(e) m(eser) Piero Gliubauazzo in la qual habita Helena Bianchinichia paga $d(e)$ fito ogni anno lire 8 soldi - ual lire 8 soldi -

Item fo speso in concier $\mathrm{d}(\mathrm{e})$ ditta lire 7 soldi 11

(fol. 9v) 24 Vna casa posta p(er) mezo la casa d(el) m(eser) Piero Gliubauazzo in la q(u)al habita Piero Vlassich dalla Vrana paga d(e) fito ogni an(n)o lire 8 soldi -

Item fo speso in concier $\mathrm{d}(\mathrm{e})$ ditta lire 3 soldi 10

25 Vna casa alla contra grande posta p(er) mezo la casa del ditto m(eser) Piero in la qual habita Vuccho Argumetich sartor paga d(e) fito ogni anno lire 9 soldi - ual lire 9 soldi -

Item fo speso in co(n)cier d(e) ditta lire 2 soldi 13

26 Vna caseta posta alla contra grande p(er) mezo la casa del ditto m(eser) Piero in la qual habita $\mathrm{m}$ (ist)ro Zorzi Taiapiera da Sibenico paga d(e) fito ogni anno lire 12 soldi - ual lire 12 soldi -

Item fo speso in co(n)cier $\mathrm{d}(\mathrm{e})$ ditta lire 3 soldi -

27 Vna caseta posta in la Strada grande p(er) mezo la casa de m(eser) Piero Gliubauaz in la qual habita Jacomo Scradignanin paga de fitto ogni anno lire 12 soldi -

Item fo speso in co(n)cier $\mathrm{d}(\mathrm{e})$ ditta lire 3 soldi 10

28 Vna caseta posta fra li fauri in la qual habita Vido Scaricich d(e) Opatiza selo paga $\mathrm{d}(\mathrm{e})$ fito ogni anno lire 12 soldi -

Item fo speso in concier de ditta lire 6 soldi -

29 Vna casa posta ap(re)sso S(an) Zuane fra li fauri in la q(u)al habita Mihouil Barzouich da Bibigne paga d(e) fito goni anno lire 7 soldi - 
Item fo speso in co(n)cier $\mathrm{d}(\mathrm{e})$ ditta lire 9 soldi $1 \frac{1 / 2}{2}$

30 Vna casa posta apresso San Zuane fra li fauri in la qual habita Ambrosio Varcich da Bibigne paga de fitto ogni anno lire 8 soldi - ual lire 8 soldi -

Item fo speso in co(n)cier $\mathrm{d}(\mathrm{e})$ ditta lire 1 soldi 8

(fol. 10r) 31 Vna casa posta ap(re)sso el forno del monasterio in la qual habita mag(ist)ro Andrea Lersich pillicer paga d(e) fito ogni anno lire 8 soldi - ual lire 8 soldi -

Item fo speso in co(n)cier $\mathrm{d}(\mathrm{e})$ ditta lire 2 soldi 10

32 Vna casa posta ap(re)sso el forno p(redet)to in la q(u)al habita Dorotea Millassinouichia paga de fitto ogni anno lire 7 soldi 10 ual lire 7 soldi 10

Item fo speso in co(n)cier $\mathrm{d}(\mathrm{e})$ ditta lire 2 soldi -

33 Vna casa posta apresso el forno $\mathrm{p}(\mathrm{re})$ detto in la qual habita Matteo Druscouich detto Matuglia paga d(e) fito ogni an(n)o lire 10 soldi -

Item fo speso in co(n)cier $\mathrm{d}(\mathrm{e})$ ditta lire 3 soldi 6

34 Vna casa posta $\mathrm{p}(\mathrm{er})$ mezo forno p(redet)to in la $\mathrm{q}(\mathrm{u})$ al habita Lucia Baracouichia paga d(e) fitto ogni anno lire 8 soldi - ual lire 8 soldi -

Item fo speso in co(n)cier $\mathrm{d}(\mathrm{e})$ ditta lire 2 soldi 18

35 Vna casa $\mathrm{p}$ (er) mezo la casa del R(eueren)do Arciprete Gresogoni p(ro)indiuisa co(n) li monasterii d(e) S(an) Nicolo et S(an) Dimitri in la q(u)al habita m(eser) Lodovico d(e) Nassi paga d(e) fito ogni anno a tutti tre monasterii lire 100 soldi - tocca alla p(ar)te d(e) S(anta) Maria p(er) la lor porcion ual p(er) tutti tre anni lire 33 soldi 6 piccioli 8 lire 100 soldi -

36 Vna casa posta ap(re)sso Capeliza in la q(u)al habita Cath(arin)a d(e) Nouigradi pizzochara paga d(e) fitto ogni anno lire 6 soldi - ual lire 6 soldi -

Item fo speso in concier $\mathrm{d}(\mathrm{e})$ ditta lire 3 soldi - 
Prilog 2. Prijepis samostanskih livela u gradu i u Varošu. Izvor: IT-ASVe-0450SDC, pezzo 39, fol. 10r-12v.

(fol. 10r) Liuelli in la città delle R(euerende) Monache de S(anta) Maria

Vinc(enz)o de Tnina q(uondam) $\mathrm{m}$ (ist)ro Zuane paga per liuello d'una casa in co(n)fin de S(anta) Maria lire 4 soldi 2 all'anno

$\mathrm{M}(\mathrm{eser}) \mathrm{p}$ (rete) Zorzi Barzotto p(er) liuello d'una muracha ap(re)sso Capeliza paga ogni anno lire 3

(fol. 10v) Franc(esc)o Custurich paga de liuello p(er) una cortisella posta ap(re) sso casa sua soldi 12 al anno

Marco Batcouich zappador paga de liuello p(er) una casa posta sul campo de S(an) Luca lire 3 all'anno

Nicolo Pastrouich paga de liuello lire 2 all'anno p(er) una canaua posta apresso la Mad(onn)a de Capeliza

Dunado Pucchiaricich marinaro paga de liuello $\mathrm{p}$ (er) uno horto fo del q(uondam) meser p(rete) Simo(n) Vusiza posto in co(n)fin de S(an) Fr(ances)co ogni an(n)o lire 1 soldi 10

Don(n)a Cath(arin)a Ventura paga de liuello p(er) una casa posta ap(re)sso mangano lire 1 soldi 5 all'anno

Don(n)a Cath(arin)a Zolta Sibenzana paga de liuello ogni anno p(er) una casa posta contra el granaro del monasterio lire 2 soldi 12

Stana Bolsichia de Scardona paga de liuello ogni anno p(er) una casa posta a Santi Quara(n)ta lire una

$\mathrm{M}($ ist)ro Zuan Iuanusseuich butaro paga de liuello ogni anno lire 7 soldi $10 \mathrm{p}(\mathrm{er})$ una casa posta all'inco(n)tro della casa del q(uondam) meser Zoylo Pecchiari

Stipan Bozedareuich paga de liuello per una casetta posta in la corte Belagef p(er) mezo il forno del monasterio ogni anno lire 1 soldi 10

Zuane Malpensa marinaro paga de liuello ogni anno p(er) una casa in ditta corte lire 1 soldi 10

$\mathrm{M}($ ist)ro Piero Fiorouich paga de liuello p(er) uno uolto in Posarischie ogni anno lire 1 soldi 16

$\mathrm{M}($ ist)ro Percho fauro $\mathrm{p}(\mathrm{er})$ liuello d'un pezzo de terren co(n)tiguo alla casa sua paga ogni anno lire 1 soldi 9

Iuan Turin caleger $\mathrm{p}(\mathrm{er})$ liuello d(ella) casa paga ogni anno lire 1 soldi 5 
(fol. 11r) Carstina fiola del q(uondam) Zan Bradich paga de liuello ogni an(n)o lire 3 soldi $10 \mathrm{p}(\mathrm{er})$ una casa et muracha posta a Posarischie

Ser Piero Pribcich paga de liuello ogni an(n)o lire 4 p(er) una casa posta in confin de San Michel

M(ist)ro Simo(n) Profeta paga de liuello ogni anno lire 2 soldi $10 \mathrm{p}(\mathrm{er})$ una casa $\mathrm{p}$ (er) mezo il horto delli frat(ell)i de $\mathrm{S}(\mathrm{an}) \mathrm{D}$ (ome)nego

Conuento de S(an)ta Cath(arin)a paga de liuello p(er) doi casete tolto in ditto co(n)uento lire 4 soldi 10 all'anno

Luca Pauflouich paga de liuello p(er) una casa posta p(er) mezo la casa del q(uondam) Meser $\mathrm{Za}(\mathrm{n})$ Batt(ist)a Boccarich lire 2 soldi 10

Nicolo Matessich de Ponta Micha paga de liuello p(er) una casa posta ap(re)sso San Dimitri lire 3 all'anno

Meser Franc(esc)o de Begna q(uondam) meser Marco Ant(oni)o paga de liuello $\mathrm{p}(\mathrm{er})$ una sua camera posta sop(ra) la lozetta in co(n)fin de S(an) Lorenzo lire sei all'anno

M(ist)ro Zan de Como sartor paga de liuello p(er) una casa ap(res)so S(an) Nicolo lire 3 al anno

Meser Zan Antonio de Pontremolo paga de liuello p(er) una casa in la q(ua)l sono doi forni p(er) mezo la casa del q(uondam) Meser Zoylo de Pecchiari in co(n)fin de S(an)ta Mari della Piazzola lire diese all'anno

Meser Batt(ist)a Boccarich p(er) liuello d'una casa p(er) mezo la casa della sua habitation paga al anno lire 14

Mad(onn)a Marchettta Pecchiari p(er) liuello de doi casette poste ap(res)so Capeliza paga all'anno lire 2

(fol. 11v) Liuelli in Borgo de Zara delle R(euerende) Monache de Santa Maria

Simon Possilouich del borgo paga de liuello ogni anno p(er) una casa et horto app(re)sso S(anta) Croce lire 3 soldi 4

Vido Barich et Draghissa Dianouich pagano de liuello ogni an(n)o p(er) una casa et horto lire 3 soldi 8

Mattio Lalich p(er) liuello de doi casette et uno horto paga ogni anno lire 4 soldi 16

Cath(arin)a Bogaucichia q(uondam) Simo(n) ouer Busnosichia, p(er) liuello de casa et horto paga ogni anno lire 3 soldi 10 
Iuan Ostrouiza del borgo paga de liuello ogni anno p(er) una casa et horto app(re) sso Ogni Santi lire 3

Iuan Telletina paga de liuello $\mathrm{p}(\mathrm{er})$ una casa et horto ap(re)sso S(anta) Croce ogni an(n)o lire otto

Gregorio Calebich p(er) liuello de casa et horto paga al anno lire 4

Mara r(elitta) q(uondam) Luca Calebich p(er) liuello d(ella) casa et horto paga all'anno lire 4

Martin Carglien p(er) liuello d'una casa paga all'anno lire 1 soldi 10

Iuan Zelencouich del borgo p(er) liuello d'una casa et horto paga all'anno lire 5 soldi 2

(fol. 12r) Jacomo Sugarich del borgo paga de liuello p(er) una casa et horto lire quattro soldi 5 all'anno

Thomaso Bodouich p(er) liuello d'uno hortiselo, paga ogni anno lire 1 soldi 4 Luca Flurich p(er) liuello d(ella) casa et horto paga all'anno p(er) se et Vido Flurich lire 3 soldi 10

Clara Vilenichia p(er) liuello d'una casa et horto paga all'an(n)o lire 4 soldi 10 Item $\mathrm{p}$ (er) liuello d'uno loco uacuo posto in cortiuo suo paga all'anno soldi 10 Zorzi Medacouich del borgo per liuello d'una casa paga all'anno lire 1 soldi 10 Jacomo Raducich per liuello de casa et horto paga all'anno lire 4 soldi 10 Simon Checinof per liuello de casa et horto Urouignah paga all'anno lire 3

Cath(arin)a r(elitta) q(uondam) Raia del borgo per liuello de una casa paga all'anno lire 1 soldi 18

Luca Martincich del borgo p(er) liuello de casa et horto paga all'anno lire 1 soldi 8 Luca Mihaglich p(er) liuello de casa et horto ap(re)sso Santa Croce paga all'anno lire 5 soldi 10

Martin Bibigna p(er) liuello de casa et horto a Pogliana paga all'anno lire doi soldi 15 / Item p(er) un'altro ortiselo ap(re)sso Santa Croce paga all'an(n)o lire 1 soldi 10 val i(n) tutto lire 4 soldi 5

(fol. 12v) Zorzi Sferich zenero de Butrich p(er) liuello de casa et horto ap(re)sso il ponton paga all'anno lire 6

Rusiza Mesodiglichia de Articouo p(er) liuello de casa et horto a Pogliana paga al anno lire 1 soldi 10

Iuan Radanouich p(er) liuello de casa et horto a Pogliana paga all'anno lire 1 soldi 10 
Piero Sladich zapador p(er) liuello d'uno horto ap(re)sso il bastion paga all'anno lire 4 soldi 10

Zuane Squerglich p(er) liuello de casa et horto ap(re)sso il bastion ouer po(n)ton paga al'an(n)o lire 2

Mattia Voichouichia p(er) liuello de casa et horto p(er) mezo il ponton paga all'anno lire 1 soldi 4

Thomaso Sternocosich p(er) liuello d'uno hortiselo post p(er) mezo il ponton paga all'an(n)o soldi 12

Catherina Vranca per liuello de casa et horto $\mathrm{p}(\mathrm{er})$ mezo il ponton paga ogni anno lire 1 soldi 10

Simon Progarich p(er) liuello de casa et horto ap(re)sso S(anta) Croce paga ogni anno lire 3 


\section{Neobjavljeni izvori}

Italija - Archivio di Stato di Venezia - fond 0450 - Sopraintendenti alle decime del clero (IT-ASVe-0450-SDC).

\section{Objavljeni izvori i literatura}

Anzulović, Ivna. „Crkva sv. Marije od Duba ili Stublja, njezin položaj i srednjovjekovna sela na području nekadašnjeg Obrovca jugoistočno od Zadra”. Diadora 22 (2007): 301-339.

Anzulović, Ivna. „Razgraničenje između mletačke i turske vlasti na zadarskom prostoru 1576. godine, nakon Ciparskog rata". Zadarska smotra 47 (1998), br. 1-3: 53-150.

Bianchi, Carlo Federico. Fasti di Zara. Zadar: Tipografia Woditzka, 1888.

Bianchi, Carlo Federico. Zara Cristiana, svezak I. Zadar: Tipografia Woditzka, 1877.

Čoralić, Lovorka. „Zemljišni posjedi dominikanskog samostana u Zadru u XVII. i XVIII. stoljeću”. Croatica Christiana periodica 18 (1994), br. 33: 213-224.

Fabijanec, Sabine Florence. „Od tržnice do luke. Trgovačka svakodnevica kasnoga srednjeg vijeka”. Kolo: časopis Matice hrvatske 16 (2006), br. 4: 188-228.

Ferro, Marco. Dizionario del diritto comune e veneto, svezak II. Venecija: Andrea Santini e figlio, 1847.

Filipi, Amos Rube. „Samostan i crkva Sv. Marije u Zadru prema dokumentima iz g. 1579. i 1603”. U: Kulturna baština samostana Sv. Marije u Zadru, uredili Grga Novak i Vjekoslav Maštrović, 229-264. Zadar: Institut Jugoslavenske akademije znanosti i umjetnosti u Zadru, 1968.

Grgić, Marijan. Časoslov opatice Čike. Zagreb: Kršćanska sadašnjost, 2002.

Jakšić, Nikola. Hrvatski srednjovjekovni krajobrazi. Split: Muzej hrvatskih arheoloških spomenika - Split, 2000.

Kolanović, Josip. „Šibenski metrološki sustav u XV. stoljeću”. Arhivski vjesnik 37 (1994): 189-207.

Kolanović, Josip. „Zadarska nadbiskupija prema izvješćima ad limina 1599. 1797." U: Sedamnaest stoljeća zadarske Crkve. Zbornik radova znanstvenog skupa o 1700. obljetnici mučeništva sv. Stošije (Anastazije) 16. - 18. studenoga 2004., uredio Livio Marijan, 379-413. Zadar: Zadarska nadbiskupija, 2010.

Neralić, Jadranka. Put do crkvene nadarbine. Split: Književni krug, 2007.

Novak, Grga; Maštrović, Vjekoslav, ur. Kulturna baština samostana Sv. Marije u Zadru. Zadar: Institut Jugoslavenske akademije znanosti i umjetnosti u Zadru, 1968. 
Novak, Viktor, ur. Zadarski kartular samostana Svete Marije. Zagreb: Jugoslavenska akademija znanosti i umjetnosti, 1959.

Ostojić, Ivan. Benediktinci u Hrvatskoj i ostalim našim krajevima, svezak I. Split: Benediktinski priorat - Tkon, 1963.

Ostojić, Ivan. Benediktinci u Hrvatskoj i ostalim našim krajevima, svezak II. Split: Benediktinski priorat - Tkon, 1964.

Peričić, Eduard. „Samostan sv. Marije u Zadru od njegova osnutka do danas”. U: Kulturna baština samostana Sv. Marije u Zadru, uredili Grga Novak i Vjekoslav Maštrović, 7-59. Zadar: Institut Jugoslavenske akademije znanosti i umjetnosti u Zadru, 1968.

Raukar, Tomislav. Zadar u XV. stoljeću. Ekonomski razvoj i društveni odnosi. Zagreb: Sveučilište u Zagrebu, Institut za hrvatsku povijest, 1977.

Raukar, Tomislav; Petricioli, Ivo; Švelec, Franjo; Peričić, Šime. Zadar pod mletačkom upravom. Zadar: Narodni list; Filozofski fakultet Zadar, 1987.

Smiljanić, Franjo. „Jesu li komunalne utvrde - stražice na zadarskom komunalnom kopnenom posjedu doista kasnoantičke?". Vjesnik Arheološkog muzeja u Zagrebu 43 (2010), br. 1: 399-413.

Smiljanić, Franjo. „O položaju zadarskog posjeda Mons Ferreus”. Diadora 22 (2007): 281-300.

Vežić, Pavuša. „Bazilika Sv. Ivana Krstitelja (Sv. Nediljica) u Zadru. Prilog poznavanju ranoromaničke arhitekture u Dalmaciji”. Radovi Instituta za povijest umjetnosti 23 (1999): 7-16.

Vežić, Pavuša. „Zvonik i kapitularna dvorana Samostana Sv. Marije Male u Zadru: kraljevska kapela - kapitul - sakristija - memorija". U: Laude nitens multa. Zbornik radova s kolokvija u povodu 900. obljetnice Vekenegina epitafa, uredili Pavuša Vežić i Ivan Josipović, 95-141. Zadar: Sveučilište u Zadru, 2018.

Vežić, Pavuša; Josipović, Ivan, ur. Abbatissa ingenuitate precipua. Zbornik radova sa znanstvenog kolokvija „950. obljetnica Samostana benediktinki Sv. Marije u Zadru (1066. - 2016.)". Zadar: Sveučilište u Zadru; Samostan benediktinki Sv. Marije u Zadru, 2020.

Vežić, Pavuša; Josipović, Ivan, ur. Laude nitens multa. Zbornik radova s kolokvija u povodu 900. obljetnice Vekenegina epitafa. Zadar: Sveučilište u Zadru, 2018.

Zaninović-Rumora, Marija. „Stare mjere za površinu u sjevernoj Dalmaciji”. Radovi Zavoda za povijesne znanosti HAZU u Zadru 35 (1993): 121-135.

Zaninović-Rumora, Marija. „Stare mjere za tekućine”. Radovi Zavoda za povijesne znanosti HAZU u Zadru 39 (1997): 183-193. 


\section{Zdenko Dundović*}

\section{Estates of the Monastery of St Mary in Zadar during the $16^{\text {th }}$ Century (1562-1564)}

\section{Summary}

Based on an official report of the legal representative (procurator) of the Benedictine nunnery of St Mary in Zadar, the paper discusses the size of monastic estates in the second half of the $16^{\text {th }}$ century (1562-1564). The report is today preserved in the Venetian magistracy collection Sopraintendenti alle decime del clero at the State Archives of Venice (Archivio di Stato di Venezia). Considering the value of the recorded data and the fact that the Archive of the monastery of St Mary in Zadar, as far as is known, has no systematic data on its estates for the period under consideration, the report on the estates of the Benedictine nuns of St Mary is an excellent contribution to the knowledge of the economic situation and transactions of Zadar's nuns in the $16^{\text {th }}$ century and complements the results of previous scholarly research. In addition, these data, especially the list of colons in individual villages owned by the monastery, are a first-class source for exploring the historical anthroponymy and toponymy of Zadar and its wider surroundings.

Keywords: monastery of St Mary, Benedictine nuns, Zadar, estates, $16^{\text {th }}$ century 